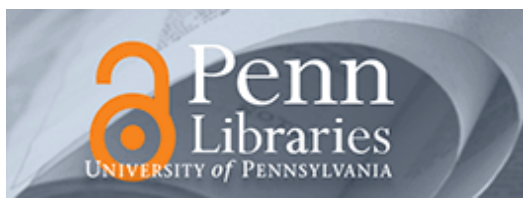

University of Pennsylvania ScholarlyCommons

Wharton Pension Research Council Working

Papers

Wharton Pension Research Council

$3-1-2012$

\title{
Target-Date Funds in 401(k) Retirement Plans
}

Olivia S. Mitchell

The Wharton School, University of Pennsylvania, mitchelo@wharton.upenn.edu

Stephen P. Utkus

Vanguard Centerfor Retirement Research, steve_utkus@vanguard.com

Follow this and additional works at: https://repository.upenn.edu/prc_papers

Part of the Economics Commons

Mitchell, Olivia S. and Utkus, Stephen P., "Target-Date Funds in 401(k) Retirement Plans" (2012). Wharton Pension Research Council Working Papers. 141.

https://repository.upenn.edu/prc_papers/141

This paper is posted at ScholarlyCommons. https://repository.upenn.edu/prc_papers/141

For more information, please contact repository@pobox.upenn.edu. 


\title{
Target-Date Funds in 401(k) Retirement Plans
}

\begin{abstract}
Individual responsibility for portfolio construction is a central theme for defined contribution pensions, yet the rise of target-date funds is shifting investment decisions from workers back to employers. A complex choice architecture including automatic enrollment, reenrollment, and fund mapping, is increasing the number of participants defaulting into employer-selected target-date funds. At the same time, portfolios of non-defaulted participants undergo sizeable changes, with equity share ratios widening by over 40 percent points between younger/older participants. Among active decision-makers, these funds act as a form of implicit employer-provided lifecycle investment advice. More broadly, our findings highlight malleable preferences among retirement investors and a demand for default-based guidance or simplified advice for households facing complex choices.
\end{abstract}

\section{Disciplines}

Economics 


\title{
Target-Date Funds in 401(k) Retirement Plans
}

\author{
Olivia S. Mitchell and Stephen P. Utkus
}

March 2012

\author{
PRC WP2012-02 \\ Pension Research Council Working Paper \\ Pension Research Council \\ The Wharton School, University of Pennsylvania \\ 3620 Locust Walk, 3000 SH-DH \\ Philadelphia, PA 19104-6302 \\ Tel: 215.898.7620 Fax: 215.573.3418 \\ Email:prc@wharton.upenn.edu \\ http://www.pensionresearchcouncil.org
}

This research is part of the NBER programs on Aging and Labor Studies and the Household Finance Working Group. It was undertaken pursuant to a grant from the US Social Security Administration (SSA) to the Michigan Retirement Research Center (MRRC). This research support is gratefully acknowledged along with that of the Pension Research Council at The Wharton School of the University of Pennsylvania and Vanguard. The authors thank Yong Yu for exceptional research assistance and acknowledge Vanguard's efforts in the provision of recordkeeping data under restricted access conditions. The authors also thank John Ameriks and Jean Young for helpful comments. All findings, interpretations, and conclusions of this paper represent the views of the authors and not those of the Wharton School or the Pension Research Council, the SSA, any agency of the Federal Government, Vanguard, the MRRC, or any other institution with which the authors are affiliated. (C2012 Mitchell and Utkus. All rights reserved. 


\title{
Target-Date Funds in 401(k) Retirement Plans
}

\begin{abstract}
$\underline{\text { Abstract }}$
Individual responsibility for portfolio construction is a central theme for defined contribution pensions, yet the rise of target-date funds is shifting investment decisions from workers back to employers. A complex choice architecture including automatic enrollment, reenrollment, and fund mapping, is increasing the number of participants defaulting into employer-selected targetdate funds. At the same time, portfolios of non-defaulted participants undergo sizeable changes, with equity share ratios widening by over 40 percent points between younger/older participants. Among active decision-makers, these funds act as a form of implicit employer-provided lifecycle investment advice. More broadly, our findings highlight malleable preferences among retirement investors and a demand for default-based guidance or simplified advice for households facing complex choices.
\end{abstract}

\section{Olivia S. Mitchell}

International Foundation of Employee Benefit Plans Professor

The Wharton School, University of Pennsylvania

3620 Locust Walk, Suite 3000-SHDH, Philadelphia, PA 19104

Tel. 215-898-0424

mitchelo@wharton.upenn.edu

\section{Stephen P. Utkus}

Principal, Vanguard Center for Retirement Research

100 Vanguard Boulevard, M38

Malvern, PA 19355

Tel. 610-669-6308

steve_utkus@vanguard.com 


\title{
Target-Date Funds in 401(k) Retirement Plans
}

\author{
Olivia S. Mitchell and Stephen P. Utkus
}

Individual responsibility for portfolio construction has long been central to defined contribution (DC) pensions in the United States, particularly in 401(k) retirement plans. ${ }^{1}$ The employer offering a 401(k) plan is responsible for selecting the plan's menu of investment offerings, but employees retain ultimate responsibility for portfolio construction. Nonetheless, an ongoing concern with such arrangements is that many participants seem ill-equipped to make such decisions, whether due to lack of financial sophistication or behavioral biases in decisionmaking. $^{2}$ Over the past decade, one response to this concern in the retirement saving marketplace has been the introduction of investment offerings known as target-date funds (TDFs) in 401(k) plans. These funds aim to simplify employee investment decision-making and delegate important portfolio choices to investment managers selected by the employer.

Target-date funds consist of a series of investment offerings with portfolio allocations described in terms of an expected year of retirement. The funds are usually offered in five-year increments (e.g., a 2010, 2015, 2020, etc., fund); a typical series may include up to a dozen funds. Participants making active choices can choose among these funds and other plan options; defaulted participants are invested by the employer in a single target-date fund based on employees' current ages and assumed retirement dates. In what is often referred to as the "equity glide path," equity allocations are highest for young participants farthest from retirement (e.g. the 2050 fund) and lowest for those approaching and in retirement (e.g. a current-dated option such as the 2010 fund). Once a participant's account is invested in a given target-date fund, his portfolio equity share is lowered over time due to age-related rebalancing by the fund manager (who also handles all other portfolio management decisions). Target-date funds have grown rapidly in the U.S. From 2000 to 2010, assets rose from $\$ 6$ to $\$ 245$ billion, and 70\% of DC plans

\footnotetext{
${ }^{1}$ Here we use the term 401(k) plans to refer broadly to private-sector defined contribution plans which can include profit-sharing, money purchase, and 403(b) plans along with 401(k) plans. The importance of 401(k) plans in the retirement portfolio is discussed by Samwick and Skinner (2004).

${ }^{2}$ See Benartzi and Thaler (2001), Lusardi and Mitchell (2007, 2011), and Mottola and Utkus (2008) for extensive references.
} 
offered target-date funds and 36\% of all DC plan participants held positions in these funds (as of 2010). ${ }^{3,4}$

The growing use of target-date funds is influenced by two decision-making mechanisms. First, encouraged by qualified default investment alternative (QDIA) regulations issued by the U.S. Department of Labor in 2007, employers have added target-date funds to default arrangements including automatic enrollment, reenrollment, and fund mapping frameworks. ${ }^{5}$ In such settings, participant contributions are directly invested in a fund designated by the employer. Second, participants not subject to such default arrangements are also increasingly investing in the funds on their own. In these active or voluntary choice settings, a participant's selection of a target-date fund delegates portfolio construction tasks to the fund's manager.

Target-date funds offer three distinct portfolio features to investors, regardless of whether the funds are chosen actively or by default. The first is a portfolio "prepackaging" or convenience feature, whereby contributions are directed to multi-asset class funds designed to be “all-in-one” portfolios. The second entails a current portfolio allocation with a decision heuristic based on the participant's expected retirement age. This heuristic is arguably simpler than the process of creating a portfolio from a list of individual equity, fixed income, and/or balanced funds. A third feature is an age-based rebalancing service, whereby risk exposure is reduced automatically over time by the fund manager. The rebalancing can be viewed as a form of commitment device: with a current-day decision to invest in a target-date fund, the employee is committed to a future portfolio risk-reduction strategy, implemented by the fund manager, which the participant might otherwise fail to implement on his own.

\footnotetext{
${ }^{3}$ See ICI (2011), Figures 7.8 and 7.22, and Holden, VanDerhei, Alonso and Bass (2011), Figure 22. Target-date funds accounted for an estimated 10 percent of private DC plan assets in 2009. Total target-date fund assets, including monies in DC plans, IRAs and elsewhere, grew from \$9 billion in 2000 to $\$ 340$ billion in 2010 (ICI, 2011). These data are based on mutual fund assets and do not include the growing pool of target-date assets invested in collective trusts or commingled funds, used by larger retirement plans. In $201068 \%$ of DC participants were offered target-date funds, and 53\% of those offered invested in them (Holden et al., 2011). See also Vanguard (2011) and Copeland (2011) for additional information on target-date fund adoption.

${ }^{4}$ For other studies on target-date funds, see Agnew, Szykman, Utkus and Young (2011); Ameriks, Hamilton and Ren (2011); Pagliaro and Utkus (2011); and Park (2009).

${ }^{5}$ Eligible QDIAs under the 2006 Pension Protection Act include target-date funds, traditional balanced funds, and managed account advice services. When a plan sponsor defaults a participant to a QDIA and follows regulatory requirements for, among other items, notification and disclosure to participants, and offers a pre-emptive right for participants to "opt out" to alternative investments, the sponsor receives so-called 404(c) protection for participant portfolio choices, meaning there is a presumption that the employer is not liable for participant portfolio decisions when they invest in the QDIAs. Irrespective of this fiduciary protection, the sponsor, as with all plan investments, retains fiduciary liability for selecting and monitoring the QDIA itself.
} 
We seek to evaluate how the introduction of target-date funds influences patterns of both adoption and portfolio construction within 401(k) plans. We draw on a longitudinal dataset from a major 401(k) plan provider, which offers a unique natural experiment in which to observe the funds' evolution over the 2003-10 period. Target-date funds were available in our dataset to more than two million participants in over one thousand DC plans by 2010. The longitudinal nature of the dataset permits us to examine the complex dynamics of target-date behaviors over time, including the distinct reactions of existing employees versus new hires to the funds' introduction, and the effect of changing employer default policies. In the first part of the paper we consider adoption patterns: who adopted the funds, whether they adopted them as a single holding ("pure investors”) or combined them with other options (“mixed investors”), and how default arrangements versus voluntary choice influenced adoption results. In the second part of our paper, we consider changes in participant portfolios when target-date funds are adopted voluntarily. For this analysis, we consider participants who actively switched to the new funds when the funds are first introduced. This difference-in-difference analysis permits us to isolate the treatment effects of target-date funds on portfolio composition, controlling for both observed and unobserved differences in target-date investors.

We offer several new findings. First, we document the rising demand for target-date funds among participants due to active choice, particularly among workers early in the lifecycle Employees who make active choices are equally likely to use target-date funds as pure targetdate investors, or in combination with other funds as a mixed target-date investors; this suggests that preferences for target-date features are not a binary, all-or-nothing, choice. Also, voluntary adoption of target-date funds appears relatively invariant to market conditions over time and rose slightly during the recent financial crisis.

Second, we show that a complex, default-based "choice architecture" is accelerating demand for target-date funds, and it is an important way in which the responsibility for portfolio choice transfers from workers to employers. ${ }^{6}$ Consistent with prior research (e.g. Madrian and Shea, 2001), automatic enrollment of new plan entrants into target-date funds raises adoption rates by 81 percent relative to adoption rates among non-defaulted workers. Yet other defaultbased strategies adopted by employers can also have important—and sometimes even stronger

\footnotetext{
${ }^{6}$ The term "choice architecture" was popularized by Thaler and Sunstein (2008) for a wide range of decision settings, including the retirement or pension plan context.
} 
effects-on outcomes. For instance, the simple designation of a target-date fund series as the default for administrative recordkeeping purposes raises adoption among new hires by a relative 55 percent-what we refer to as a "halo" effect just from the simple default assignment. Moreover, when an employer re-enrolls participants from a prior default fund into a new targetdate default, adoption rises by a relative 71 percent; when discontinued funds are mapped into target-date funds, target date fund adoption grows by a relative 166 percent.

Third, we demonstrate that the portfolios of participants who select target-date funds when they are first offered undergo important changes upon adoption, suggesting that the funds serve as a form of implicit investment advice for workers. ${ }^{7}$ This implicit advice feature represents a second mechanism by which responsibility for 401(k) portfolio selection is shifting from workers to employers. Portfolio changes are most dramatic for pure (single-fund) targetdate investors: the difference in equity share between the youngest and oldest participants widens by over 40 percent points. Younger participants can anticipate large increases in portfolio returns and variances, and all investors can expect to benefit from sizeable reductions in nonsystematic risk (the target-date funds in our sample are index-based). It is worth noting that participants could have pursued these investment changes on their own but did not; they occurred only as a result of the employer's decision to introduce target-date funds to the plan menu. This finding, along with our results on default effects, confirm that preferences around retirement portfolios are rather malleable: many participants are accept third-party direction of their portfolios, either by default or via simplified choice.

Following a brief overview of related research, we describe the complex decision-making architecture involved in the introduction of target-date funds to 401(k) plans. We then develop empirical models of target date adoption, followed by a difference-in-difference analysis of portfolio changes for a sample of participants adopting target-date funds when first offered. We conclude with a discussion of implications of findings for retirement policy and household financial decision-making.

\footnotetext{
7 The term “advice” has specific legal meaning under employee benefit law. Here we use the term "advice” in a practical sense, meaning reliance by the participant on the target-date fund as a portfolio choice.
} 


\section{Related Prior Research}

The concept of "choice architecture" refers broadly to the design of the decision framework governing consumer choice (Thaler and Sunstein, 2008). Behavioral elements of decision-making in the retirement setting, such as the role of default arrangements for saving and portfolio decisions, the impacts of inertia and procrastination, and the difficulty decision-makers have with complex choice sets, are all related to this concept. In our context, it is highly relevant to an analysis of the impact of default investment designations in retirement plans, as well as the simplifying decision heuristic associated with choosing target-date funds.

Several prior studies have examined how defaults influence workers' saving decisions (c.f. Carroll, Choi, Laibson, Madrian and Metrick, 2009; Choi, Laibson, and Madrian, 2004; Choi, Laibson, Madrian, and Metrick, 2003, 2006; Nessmith, Utkus and Young, 2007). Others explore how defaults affect portfolio allocation and trading choices in retirement plans and personal saving accounts (c.f. Agnew, Balduzzi and Sunden, 2003; Ameriks and Zeldes, 2004; Benartzi, 2001; Benartzi and Thaler, 2001, 2002; Benartzi, Peleg and Thaler, 2007; Calvet, Campbell, and Sodini, 2009; Mitchell, Mottola, Utkus and Yamaguchi, 2006a, 2006b; O’Donoghue and Rabin, 1999; 2001). Our research is most closely related to studies showing that retirement plan investment menus can shape, or "frame," individual portfolio allocation patterns due to inertia or naïveté (c.f. Benartzi and Thaler, 2001, 2002; Huberman and Jiang, 2006; Brown, Liang and Weisbenner, 2007; Thaler and Sunstein, 2008; and Tang, Mitchell, Mottola, and Utkus, 2010), or in reaction to excessive complexity (also known as "choice overload;” c.f. Iyengar, Huberman, and Jiang, 2004; Iyengar and Kamenica, 2010). There is also a related literature on whether participants making portfolio choices make investment errors, due to investment illiteracy or behavioral biases (c.f. Barber and Odean 2001; Benartzi and Thaler, 2001, 2002; Lusardi and Mitchell, 2007, 2011; Mottola and Utkus, 2008; Mitchell and Lusardi, 2011).

In what follows, we examine two aspects of choice architecture in the retirement saving context, namely the effect of default investment designations on $401(\mathrm{k})$ portfolio choice, encouraged by federal regulatory policy under the Pension Protection Act and implemented over the past decade by employers in 401(k) plans; and the simplifying choice mechanism embedded in target-date funds, whereby portfolio selection is reduced to the choice of an expected retirement age. 


\section{1(k) Plan Menus and Participant Portfolios}

Our analysis draws on data for employers sponsoring 401(k) plans who introduced targetdate funds over the period 2003-10. The data are derived from the Vanguard 401(k) recordkeeping system, and the target-date funds offered were Vanguard-designed target-date funds. Table 1, Panel A, shows the range of target-date funds arrayed by their target maturity dates; each involves a different mix of passively-managed U.S. equity (including large-, midand small-capitalization stocks), international equity (both developed and emerging markets), and U.S. high-quality bonds. As of December 2010, for instance, total equity exposure in the funds for younger participants averaged 90 percent (in the 2040 through 2055 Funds) versus 29 percent for older participants in the Income Fund (intended for retirees). ${ }^{8}$

\section{Table 1 here}

Target-date funds have often been selected by employers as a replacement for (or in addition to) so-called "static allocation" or risk-based asset allocation funds; the latter are prepackaged investment offerings where portfolios differ solely based on equity fractions with no implied age glide path. ${ }^{9}$ Panel B of Table 1 outlines how our 401(k) plans added target-date funds over time, conditional on having had pre-existing static allocation offerings. In 47 percent of the plans, target-date funds were introduced de novo, while in the remaining 53 percent of the plans, participants had been previously offered static allocation funds. In the latter group, one set of firms added target-date funds to a menu that included pre-existing static allocation funds, while another set switched or "mapped" existing participant accounts from static allocation to target-date funds. ${ }^{10}$ Controlling on the prior presence of static allocation funds is important, as it helps identify groups of employees with a taste for portfolio "prepackaging," albeit without the age-based equity glide path inherent in target-date funds.

\footnotetext{
${ }^{8}$ The Vanguard funds are all indexed except for holdings of inflation-indexed bonds, which materially affect only a small fraction of the portfolios of participants in retirement; accordingly we refer to the funds as indexed. Fees for the funds were below $0.20 \%$ during the 2003-10 period; at the end of our analysis period, even lower-cost versions of the target-date funds were introduced in certain large plans. During 2010 some target-date funds offered by other investment managers were introduced into the sample, but they account for less than $1 \%$ of sample participants.

${ }^{9}$ When static allocation funds are offered, participants are presented with a selection of three or more funds of varying risk profiles (such as conservative, moderate, or aggressive). There is no age-based rebalancing. Defaulted participants are typically allocated to a moderate- or low-risk portfolio at the employer's direction.

${ }^{10}$ In the case of mapping from static allocation to target-date funds, sponsors can either switch all participant static allocation balances and contributions into the new funds, or allow existing balances to remain undisturbed while switching future contributions into the new funds. In both cases, the new target-date allocations reflect the sponsor's decision to move the money, rather than representing an active employee election.
} 
To analyze adoption behavior, we developed a panel of 401(k) plans over the 2003-10 period which introduced target-date funds. By December 2010, the sample included 1,008 plans offering target-date funds covering more than 1.8 million active participants. ${ }^{11}$ Importantly, we only include plans for which we observe plan and participant records both prior to and subsequent to the introduction of the target-date funds. ${ }^{12}$ We included all participants entering and leaving the plans due to normal workforce turnover, so the number of participants totaled over 2.2 million. Participants were observed monthly, so the total number of observations was 62.5 million.

The dataset includes several variables relevant to whether participants selected a targetdate fund actively or were defaulted to it through one or more means, as described in more detail below. Participant demographic information includes 401(k) account balances, investment holdings, and contribution patterns, as well as key socioeconomic characteristics including age, sex, household income, job tenure, and non-retirement financial wealth. ${ }^{13}$ We also have features pertinent to plans' investment menus offered, including the number and types of investment funds along with other plan design details such as the availability of plan loans or employer stock. Our dataset includes monthly returns for all investments offered over a 13-year period (including the eight-year period under analysis as well as the preceding five years).

Table 2 summarizes characteristics of the plans and participants. ${ }^{14}$ Four variables capture aspects of the default architecture (Column 1). The variable Default indicates, at the plan level, whether the target-date series was designated as the plan's default option; around 80 percent of participants were in plans where target-date funds were thus designated. A second default architecture variable, New-hire auto enrollment, indicates whether new hire automatic enrollment was a plan feature, regardless of the type of default fund used by the plan. ${ }^{15}$ Over 48

\footnotetext{
${ }^{11}$ Active 401(k) participants are those who are currently contributing to their employer's retirement plan.

${ }^{12}$ Plans transferring to the Vanguard recordkeeping service for the first time during our sample period and adopting target-date funds at that point are not included in our sample because we cannot observe plan holdings prior to the funds' introduction.

${ }^{13}$ Household income and non-retirement wealth are provided by Acxiom; non-retirement wealth amounts are imputed using zip code (zip+4) averages.

${ }^{14}$ The Online Appendix describes dataset characteristics by year and overall.

${ }^{15}$ Under new-hire automatic enrollment, newly eligible participants have contributions deducted automatically from their first eligible pay (with the right to opt out); their contributions are invested in the plan's designated default fund. Our automatic enrollment indicator is for new hires only. Some employers have returned to "sweep" (i.e., automatically enroll) existing eligible non-participants. But because our dataset did not include an indicator for such "sweeps," any automatic enrollment estimate should be viewed as a lower bound of the actual figure.
} 
percent of participants were in plans where new hires were automatically enrolled. In total, 19 percent of participants were automatically enrolled as new hires-in other words, as employees who joined plans under new-hire automatic enrollment (not shown in Table 2).

Table 2 here

Reenrollment, the third default variable, indicates at the participant level whether participants were invested in a prior default fund and automatically switched by the employer to a new default. Although reenrollment as a plan design strategy can be used in a variety of settings, we consider it only in the case of a sponsor-directed change in default funds. ${ }^{16,17}$ One and one-half percent of our participant sample underwent a default fund reenrollment during the period. A fourth default variable is Mapping, relevant when an employer discontinued a fund option in the plan (perhaps because the employer as fiduciary no longer deemed the fund appropriate). The Mapping variable indicates that a participant was automatically shifted from a closing fund to the plan's newly designated default option. ${ }^{18}$ In our sample, just over four percent of participants saw one or more funds discontinued and all or part of contributions transferred to a new default fund.

In terms of target-date portfolio behavior, 41 percent of participants in the full sample (nearly 912,000 individuals) adopted or were defaulted to target-date funds between 2003 and 2010 (Table 2, Column 1). To define target-date fund adoption, we focus on total contributions (employer and employee) to target-date funds, since contributions are most reflective of participants' forward-looking intentions and are unbiased by past asset holdings. Almost 30 percent of participants were "pure" target-date fund (TDF) investors, meaning that all contributions were directed to a single target-date fund. The remaining 12 percent of cases were of the "mixed" target-date fund sort, meaning that these employees contributed to a target-date

\footnotetext{
${ }^{16}$ Reenrollment refers to the process of switching participant assets and contributions to a newly-designated qualified default investment alternative (QDIA), such as a target-date fund. Under federal regulations, participants are given prior notice that their assets and contributions are to be transferred to the newly designated default fund and given the right to make an alternative investment election. Reenrollments are typically undertaken upon recordkeeper change, a change in the investment menu, or a change in defaults, although sponsors may undertake reenrollments purely to improve portfolio diversification within the plan. See Vanguard (2008) and Mottola and Utkus (2009).

${ }^{17}$ While we do not have a specific indicator for default fund reenrollments, we estimate this from the time series data using two rules: (1) an employer changes the default at a given time $t$, and (2) within $t+6$ months, all participant contributions change from the prior to the new default.

${ }^{18}$ We use the term "mapping” in a generic rather than legal sense. In a legal sense, "mapping” refers to the rules governing the transfer of assets from a discontinued fund option into a new, "like" investment option. We use the term "mapping" as it is used colloquially — to refer to the transfer of the discontinued fund's assets into the plan's designated default option.
} 
fund along with other funds. ${ }^{19}$ In other words, measured by total contributions, the ratio of pure to mixed target-date investors was 2.5:1. Pure target-date fund investors were generally younger, more female, and had low/moderate incomes and lower balances (Table 2, Column 2). Mixed target-date fund investors had the opposite characteristics and above-average balances (Table 2, Column 3). A point worth special note is that 42 percent of the sample was classified as "new entrants." As noted above, a plan entered our sample in the month it added target-date funds, at which point all then-current participants were classified as “existing.” A "new entrant” was anyone who entered a 401(k) plan with target-date funds included in the menu. ${ }^{20}$

For the difference-in-difference (D-D) analysis (described in more detail below), we consider participants who voluntarily switched to a target-date investment for all or part of their portfolios within subsequent six months of the funds' first appearance in the 401(k) plan. ${ }^{21}$ These participants were subject to new target-date offerings by their employers and responded to that offering - or "treatment" - affirmatively within the subsequent six-month period. In effect, these participants can be thought of as workers with the strongest latent demand for target-date funds, as they switched to the funds within six months of the funds' introduction. Over 163,000 participants appear in the D-D sample: 69,148 were pure target-date investors (participants who switched from other holdings to a single target-date fund), and 94,288 were mixed target-date investors (participants who added a position in a target-date fund to their other investments). When compared to the full sample (Table 2, Columns 1 and 4), the D-D sample is quite similar to the full group.

\section{Factors Influencing Participant Target-Date Fund Adoption}

When a participant adopts a target-date fund, the decision may be an active choice, not influenced by employer-designated defaults, or it can involve an employer-designated default. In the former instance, no default designation is made; the plan sponsor thus may add target-date funds to the menu in anticipation of (or in response to) a perceived participant need for

\footnotetext{
${ }^{19}$ A small fraction of this group contributed to multiple target-date funds and/or multiple plan options. Also, some mixed investors were "mixed" due to employer direction of employer contributions to company stock; we control for this effect with an indicator for employer securities in the plan investment menu.

${ }^{20}$ Not all new entrants are new hires. Many of the plans in our sample allow immediate eligibility for the plan to new hires, though a minority imposes a six- or 12 -month waiting period.

${ }^{21}$ We include only those plans introducing target-date funds by June 2010 in order to observe both pre- and postintroduction effects for all observations.
} 
prepackaged convenience, the simplifying decision heuristic of target-date funds or the agebased rebalancing commitment device. Existing participants may reconsider their existing portfolio choices in light of the new investment features introduced with target-date funds; new entrants will evaluate the target-date offerings along with other funds when they enroll in their plans. In the latter instance, where employers establish a default architecture, target-date funds may be selected as defaults via several channels: as a default for administrative purposes, for new-hire automatic enrollment, for reenrollment from a prior default fund, or for "mapping” of discontinued fund options.

To assess the distinct impacts of defaults and active choice on participant portfolio selection, we estimate three multivariate models of target-date fund adoption. Each relates a distinct measure of target-date adoption to default, participant, plan, and market characteristics, as in equation (1):

$$
\begin{aligned}
\text { TDFAdopter }_{i, j, t} & =\alpha \text { PARTICIPANT }+\beta P L A N+\gamma \text { ARCHITECTURE } \\
& +v_{i}+\tau_{t}+\omega_{j}+\varepsilon_{i, j, t}
\end{aligned}
$$

Here TDFAdopter ${ }_{i, j, t}$ indicates whether individual $i$ adopts a target-date fund (TDF) in plan $j$ in month $t$, measured using total contributions to target-date funds (employer and employee). In Model A, we use a Probit specification where the dependent variable takes a value of 1 if the participant contributes to a target-date fund in month $t$ ( 0 otherwise). The mean value of this time-weighted adoption rate is 31.2 percent over the 2003-10 period. Model B uses OLS and the dependent variable is the fraction of total contributions directed to the target-date fund; the mean time-weighted value for our sample is 24.1 percent. $^{22}$ Model C uses a multinomial Logit framework where the dependent variable is equal to zero if the participant is a non-target-date investor (the reference category); 1 if the participant is a "mixed" target-date fund investor (directing 1-99 percent of contributions to one or more target-date funds); or 2 if the participant is a "pure" target-date fund investor (directing all contributions to a single target-date fund). In Model C, the mean time-weighted proportion of pure investors is 20.1 percent; of mixed investors, 11.1 percent. For all three models we use the full sample described in Table 2 that includes all active participants in the 401(k) sample; this encompasses both existing participants

\footnotetext{
${ }^{22}$ This figure includes both those holding target-date funds and those with zero holdings.
} 
(those in the plan prior to the arrival of target-date funds), and new entrants (those appearing in the plan after the funds’ appearance).

Explanatory variables in equation (1) include a PARTICIPANT term which controls on a New Entrant identifier (indicating whether a participant entered a plan since the plan began offering target-date funds). We also take into account participant socioeconomic characteristics including age, income, sex, job tenure, and non-retirement financial wealth. The ARCHITECTURE vector measures aspects associated with how target-date fund funds were introduced, including the Default, New-hire automatic enrollment, Reenrollment and Mapping variables described above. The three-way interaction, Default*New_hire auto enrollment *New_entrant, indicates that a plan had new-hire automatic enrollment and also used a targetdate fund as the designated default investment. In addition, we control on the number of months since target-date funds were introduced, Months since target-date fund (and that same variable squared and scaled by 1,000), to trace out the time path of impact of target-date fund adoption. To account for cross-plan differences, the PLAN vector indicates the number of fund choices on offer, a variable indicating whether company stock was available in the 401(k) plan, and an indicator of loan availability. For reasons noted above, we also control on SA_Before which indicates whether static allocation funds were previously offered; this serves as an indicator of

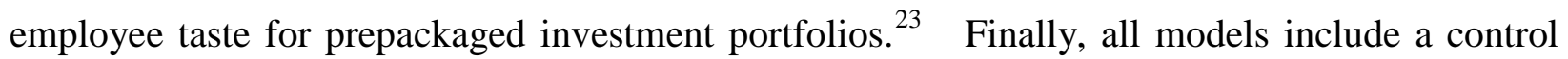
for the financial crisis, defined here as the period September 2008-June 2009.

Table 3 reports coefficient estimates and/or marginal effects for the three models summarized by equation (1), while Table 4 offers predicted effects for the five distinct decisionmaking environments in which portfolio selection and target-date fund choices were made. The first set of results in Table 4 focuses on active choices absent any default fund designations; the four remaining options present other default configurations. The baseline measures are the effects associated with active choice by non-defaulted participants (Table 4, Panel I); these are the first available estimates of target-date adoption behavior independent of default effects. During the 2003-10 period, new entrants (entering plans with target-date funds already on the menu) had a predicted target-date adoption rate of 31.4 percent. Existing participants (in the plan

\footnotetext{
${ }^{23}$ The econometric models also control for plan-level heteroskedasticity $\left(v_{i}\right)$, time fixed effects $\left(\tau_{t}\right)$, and industry fixed effects, along with missing data dummies.
} 
when target-date funds first appeared) had a predicted target-date adoption rate of less than half that level, at 14 percent.

The difference between new entrants and existing employees may be due to employer outreach surrounding the menu change: when new funds are added to a plan lineup, the change is often communicated in a brief announcement, while plan enrollment decisions generally receive a more detailed communications effort. It might also be the result of relative inattentiveness or inertia among existing employees, or the greater salience or novelty of plan features like targetdate funds to new plan entrants. The process of actively choosing target-date funds also produces a roughly equal number of pure versus mixed investors. This suggests that preferences are not binary for the prepackaging, simplified choice or age-based rebalancing features of target-date funds (Panel I, Columns 3 and 4). That is, the relative demand for these features is weaker for certain investors compared to others, so that for some, target-date funds represent only part of the endogenous portfolio selection process. ${ }^{24}$

\section{Tables 3 and 4 here}

Some of the strongest estimated effects in Table 4 are those associated with the default architecture of target-date funds. When employers designated target-date funds as the default but did not automatically enroll workers into the funds, the result was higher adoption rates (Table 4, Panel II). Among new entrants, for instance, adoption increased by over half (49 versus 31 percent), and for existing employees by more than one-third (19 versus 14 percent). This is, in effect, a "halo" default effect associated with the employer's designation of the funds as a default for administrative purposes only. Several possible mechanisms might drive this "halo" default effect. First, when target-date funds were a designated default, the employer may have devoted greater effort or resources to communicating the funds to participants. Second, some sponsors present their large fund menus in logical grouping known as "tiers;" in such arrangements, the default target-date funds are usually in the first tier or grouping. Thirdly, enrolling participants may have contacted the fund call center where an associate noted the tiering or the plan's default funds; this information might then serve as an anchoring device in a conversation about portfolio

\footnotetext{
24 Both Agnew et al. (2011) and Ameriks et al. (2011) find evidence that some participants choose a mixed strategy in an effort to enhance diversification, even though the target-date funds are highly diversified multi-asset-class funds. This view may reflect a naïve understanding of diversification or a distrust of a single fund manager and a desire to diversify among multiple managers.
} 
choice. ${ }^{25}$ Finally, the difference might represent an endogenous preference for age-based investing among employers that selected target-date funds as a default, taking into account workforce preferences or needs.

As expected, the most well-known use of a default, namely automatic enrollment of new hires, did have a substantial effect on increased adoption of target-date funds (Table 4, Panel III). The predicted adoption rate from new-hire automatic enrollment into a target-date fund was 57 percent, almost twice as large as the organic adoption rate of 31 percent among new entrants voluntarily electing target-date funds. A notable feature, not previously noted, of automatic enrollment is the tendency to produce nearly three times as many pure single-fund investors as mixed (48 versus 17 percent). But even among those automatically enrolled, the demand for a single-fund portfolio was far from universal; among some participants, a more complex portfolio remained attractive.

Somewhat unexpectedly, employers who re-enrolled workers from a previous default fund into the target-date saw as large a relative change as for automatic enrollment (Table 4, Panel IV). New entrants were 71 percent more likely to adopt target-date funds as a result of default fund reenrollment (54 versus 31 percent), and existing employees, over twice as likely (31 versus 14 percent). Default fund reenrollments also raised pure adoption by a factor of 10, relative to mixed adoption (predicted adoption of 66 percent for pure investors versus six percent for mixed investors). Employer mapping of discontinued funds into a target-date series also had a potent effect on adoption rates (Table 4, Panel V): new entrants had a predicted adoption rate of 84 percent and existing employees 65 percent. Both outcomes imply substantial inertia with respect to default effects from fund mapping. The relative difference between the two groups likely reflects the increased familiarity of new entrants with target-date funds, and thus a reduced willingness to "opt out” of fund mapping. Meanwhile, among existing employees, the predicted probability of being a mixed target-date fund investor was 55 percent versus 26 percent for being a pure target-date fund investor. This is likely because participants holding the discontinued fund had multiple asset holdings, which combined with the new target-date fund creates a mixed target-date strategy.

\footnotetext{
${ }^{25}$ Around three-quarters of Vanguard participants enroll online and one-quarter enroll by phone. Service associates have access to information on fund tiering and on the plan's designated default, making this a plausible mechanism for some participants. While service associates do not provide specific investment advice, the default fund may still serve as a reference point in portfolio allocation discussions.
} 
Though the default architecture clearly had a major influence on target-date adoption and is hence our main focus here, other factors are also worth noting. In Table 3, target-date adoption was highest among low-balance participants and it fell with rising balances. Younger participants (under age 35) were more likely to adopt target-date funds, either as pure or mixed investors. These factors suggest that workers in the earlier stages of the investment lifecycle with less financial sophistication were more attracted to target-date funds, independent of the default architecture effects. Another point worth noting is that target-date fund adoption rose during the financial crisis period after controlling for default effects. This increased taste for target-date funds during the financial crisis represented active participant choice at a somewhat higher rate than in prior or subsequent periods.

Two other subtleties are associated with the introduction of target-date funds into a plan menu. As indicated by the coefficient on the Months since target-date fund variable and its square in Table 3, target-date fund adoption evolved nonlinearly over time: each month after the funds' introduction saw adoption rates rise by 0.6 percentage points (though at a declining rate). This represents a pure time effect associated with the first appearance of the funds in a plan menu, and it implies a declining impulse function. Furthermore, offering more funds in the 401(k) menu slightly dampened target-date fund adoption, and the effect was sizeable. Having ten additional funds in the menu was associated with a five percent point reduction in the probability of adopting target-date funds, suggesting that the appeal of target-date funds depends on the breadth of the other investment offerings on the menu.

\section{Treatment Effects of Target-Date Fund Introduction}

We next consider worker demand for the unique portfolio features of target-date funds, which, as noted earlier, include the prepackaged convenience element, an initial allocation based on a simplifying decision heuristic (expected age of retirement), and a portfolio commitment device for future age-based equity share rebalancing. For this purpose, we use a difference-indifference treatment effects model, exploiting the longitudinal nature of our panel. We select participants observed both one month prior to the introduction of target-date funds to the plan menu (the pre-treatment portfolio), and then again six months afterward (the post-treatment portfolio). We consider portfolio changes separately for those who became either pure or mixed target-date investors, and we control on elements of the default architecture to isolate the effects 
of active participant choice. Importantly, we have a natural way to control for tastes for prepackaged investment portfolios, namely with the $S A \_b e f o r e$ variable, which indicates whether static allocation funds had been offered previously. As a result, the resulting demand for targetdate funds reflects a preference for the simplified current allocation heuristic (expected retirement age), the future rebalancing feature, or both.

Table 5 presents investment attributes of pure and mixed target-date fund investor portfolios before and after target-date funds entered the menu. Panel A shows the allocation of total employer and employee contributions by major asset class including cash or principalguaranteed funds (money market or guaranteed investment contracts), bonds, balanced or targetdate funds (including traditional balanced funds and static allocation funds), U.S. equities, international equities, and employer stock. Before target-date funds were added, investors held more cash, bonds, and equity funds; afterward, balanced and target-date holdings rose by 22 percentage points. It is also notable that, before the new target-date funds were introduced, many subsequent target-date investors contributed to balanced or static allocation funds; those accounted for 58 percent of subsequent pure target-date and 31 percent of mixed target-date contributions. These results underscore the importance of controlling on the prior structure of a plan's pre-existing menu design, so as to isolate the novel effect of offering target-date funds on participant behavior. After adopting these funds, pure investors reduced their cash positions by almost 22 percentage points and their US equity holdings by 12 percentage points; for them, ownership of balanced and target-date fund funds rose by 42 percentage points. Mixed investors held somewhat more aggressive pre-treatment portfolios, with only nine percent of contributions directed to cash and bonds. Among this latter group, moving into target-date funds resulted in an equal reduction in cash, U.S. equity, and company stock positions, but by only just over two percentage points.

\section{Table 5 here}

Table 5 Panel B compares on a pre/post basis, three portfolio attributes for target-date fund investors. Overall, the equity share of contributions (the percent of employer and employee contributions directed to equities) rose across all investors: ${ }^{26}$ equity allocations grew from 63 to

\footnotetext{
${ }^{26}$ Equity share is the percentage of employer and employee contributions directed to U.S. and international equity funds, company stock, and a percentage of balanced and target-date funds. The equity percentage for balanced and target-date funds was calculated based on each fund's holdings; it varies from fund to fund.
} 
76 percent of contributions, a shift of 13 percentage points. Moreover, this change was most pronounced for pure investors, where equity allocations increased by nearly 26 percentage points, compared to mixed investors where the increase was just over four percentage points (this was because pure investors began with much lower equity allocations than did their mixed counterparts). The second column of Panel B reports on a second portfolio characteristic, changes in systematic or risk-adjusted expected returns due to target-date fund introduction. A given participant's systematic return is measured as the sum of the risk-free rate over the period, $r_{f}$, and that individual's factor return, or $r_{i, t}^{e}$, derived from a three-factor asset pricing model. ${ }^{27}$ The third portfolio characteristic in Table 5 refers to the change in the investor's annualized portfolio standard deviation, $\sigma$; the fourth is the change in the ratio of idiosyncratic portfolio risk as a fraction of total portfolio variance, $N S R / T V_{i, t}{ }^{28}$ This last term describes how much of the change in portfolio variance is explained by nonsystematic or non-market factors.

In Table 5 we show that systematic returns rose for both pure and mixed investors without controlling on other factors. It is noteworthy that the resulting change in systematic

\footnotetext{
${ }^{27}$ Factor returns are computed using a three-factor model based on US equities, US bonds, and international equities because, as noted earlier, the target-date funds in our dataset are composed of index-based funds mirroring these three asset classes. To calculate portfolio returns we construct a risk-loading matrix for all $k$ investment options in our dataset by regressing the excess return (over Treasury bill returns) for each of the $k$ assets in our universe on three market indices: the value-weighted CRSP portfolio, the Barclays Aggregate Bond Index (BAB), and the Morgan Stanley Capital International (MSCI) Europe, Australia and Far East (EAFE) Index. Our period of analysis is our sample period, 2003-2010, and the five years prior, 1998-2003. The systematic return for each 401(k) investment option is simply its factor exposure times the average factor returns over the period; the participant's factor return is simply the weighted average return of his or her factor exposures over the period. The mean returns of our three factors (CRPS, BAB and EAFE) over the 156-month period are given by $\bar{r}_{f}=\left(\bar{r}_{C R S P R F, t}, \bar{r}_{B A R F, t}, \bar{r}_{M S C I R F, t}\right)$. The systematic return associated with the $k$ th asset is its factor exposure times the average factor returns over the 96 months, namely $r_{k}^{e}=b_{k}^{\prime} \bar{r}_{f}$. The ith participant's excess return reported in Panel B of Table 6 is $r_{i}^{e}=\sum_{k=1}^{N} \omega_{k, t} r_{k}^{e}$, where $\omega_{i, k, t}$ is the weight of the $k$ th fund in the ith participant's total (employer and employee) contributions made in month $t$.

${ }^{28}$ Specifically, $N S R / T V_{i, t}=\hat{\Sigma}_{i}^{i d i o} / \hat{\Sigma}_{i}$. We estimate the variance-covariance matrix for all assets $\hat{\Sigma}$, which in turn is used to estimate the total portfolio variance for the ith participant, $\hat{\Sigma}_{i} . \quad \hat{\Sigma}=\hat{\mathrm{B}}^{\prime} \hat{\Sigma}_{f} \hat{\mathrm{B}}+\hat{D}$, where $\hat{D}$ is a diagonal matrix with elements computed as the square of the $\hat{\varepsilon}_{k}$ estimated in equation (2). The asset variance can be decomposed into systematic risk, $\hat{\Sigma}^{\text {sys }}=\hat{\mathrm{B}}^{\prime} \hat{\Sigma}_{f} \hat{\mathrm{B}}$ and idiosyncratic risk $\hat{D}^{\text {idio }}$. Individual portfolio variance is then decomposed into its systematic and idiosyncratic components: $\hat{\Sigma}_{i}=\omega_{i, k, t}^{\prime} \hat{\Sigma} \omega_{i, k, t}=\omega_{i, k, t}^{\prime}\left(\hat{\Sigma}^{s y s}+\hat{D}^{i d i o}\right) \omega_{i, k, t}=\hat{\Sigma}_{i}^{s y s}+\hat{\Sigma}_{i}^{i d i o}$.
} 
returns between pure and mixed target-date fund investors is small, despite their markedly different initial risk exposures. For instance, on a "before" basis, those who became mixed target-date fund investors held 22 percentage points more equity than those who moved to pure target-date fund portfolios (70 versus 50 percent), but their annualized returns differed by only 25 basis points (5.94 versus 5. 69 percent). This is a direct reflection of the negative equity risk premium that prevailed during the period over which our portfolio characteristics are evaluated (1998-2010). ${ }^{29}$ Portfolio risk levels also increased, though much more for pure than for mixed target-date investors. We also see a drop in idiosyncratic risk, as expected, given the passive nature of the target-date fund funds introduced.

Next, we use a multivariate model of portfolio characteristics to relate these four measures - equity share, systematic return, portfolio standard deviation, and nonsystematic risk share as a fraction of total variance - to participant, plan and treatment controls. We estimate separate models for pure and for mixed target-date investors. The four outcomes are represented by a vector, PORTFOLIO $i, j, t$, with an estimating equation of the following form:

$$
\begin{array}{r}
\text { PORTFOLIO }_{i, j, t}=\alpha \text { PARTICIPANT }+\beta P L A N+\gamma T R E A T M E N T \\
+v_{i}+\tau_{t}+\omega_{j}+\varepsilon_{i, j, t}
\end{array}
$$

Model A includes just these terms, while Model B adds interaction terms to test whether specific age groups responded differently to the target-date funds treatment. ${ }^{30}$ For example, TDF _treat*Young allows us to examine the specific impact of target-date fund introduction for participants under age 35.

Table 6 presents estimated coefficients for the portfolio equity share model for pure and mixed investors. The variable TDF_treat in Model A captures the simple change in equity allocation after controlling for differences in participant and plan features, timing and industry fixed effects, plan design elements, and plan-level heteroskedasticity. All else constant, pure target-date fund investors increased their equity allocation by 20 percentage points, while the change for mixed target-date fund investors was only 4 percentage points. Model B adds

\footnotetext{
${ }^{29}$ Average annual returns over this period for the risk-free rate (U.S. Treasury bills) were $2.86 \%$, with $5.96 \%$ for U.S. bonds (the Barclays Aggregate Bond Index), 4.77\% for U.S. stocks (the CRPS value-weighted index), and $4.82 \%$ for international stocks (the MSCI index of non-U.S. stocks). In other words, during this period the U.S. and international equity risk premium were both negative (relative to U.S. bonds).

${ }^{30}$ The models also control for plan-level heteroskedasticity $\left(v_{i}\right)$, time fixed effects $\left(\tau_{t}\right)$, and industry fixed effects, along with missing data dummies. All models also include a financial crisis control.
} 
treatment interactions for participant and plan characteristics, the most important of which is with respect to age, in view of the age-based equity glide path central to target-date funds. Among both pure and mixed target-date fund investors, younger workers (under age 35) invested more in equity after target-date funds were introduced (TDF_treat +TDF_treat*Young), whereas older investors (over age 55) somewhat reduced their equity share.

\section{Table 6 here}

Figure 1 reports predicted changes in equity allocations by age (holding all other variables at sample means). Among pure investors younger than age 35, equity allocations rose by 41 percentage points when target-date funds were added to the menu; for pure investors age 35-54, equity allocations increased by 21 percentage points, and for those age 55+, the change was only 0.2 percentage points. In other words, the young-old age gradient steepened by more than 40 percentage points for participants switching all of their contributions to target-date funds. Among mixed investors, while there was still a change in the age gradient, the relative increase was smaller, by about 11 percentage points. ${ }^{31}$

It is important to emphasize that these effects occurred solely due to introduction of the target-date funds in the 401(k) plan by employers. Prior to the appearance of target-date funds, participants choosing target-date funds could have made similar equity share choices on their own. But they chose not to until the target-date fund "treatment" was introduced by their employers, ${ }^{32}$ Additionally, these estimates control for default effects, prior preference for “prepackaged" portfolios, and, with our difference-in-difference approach, unobservable employee traits that might have otherwise influenced these changes.

Next we consider the three other portfolio efficiency measures. As depicted in the first two columns of Table 7, pure target-date fund investors' expected systematic returns rose by an annual 65 basis points as a result of the switch to target-date funds. Among pure investors under age 35, they grew by 91 basis points (68 plus 23 basis points); among pure investors age 55+, by 46 basis points (68 less 22 basis points). For mixed target-date fund investors, depicted in the next two columns of Table 7, changes were smaller for all mixed investors and by age group. Given the negative equity risk premium during our evaluation period, these return differences are

\footnotetext{
${ }^{31}$ Alternatively these differences, which we describe as age-related, could be cohort-related.

${ }^{32}$ Tang, Mitchell, Mottola, and Utkus (2010) show that virtually all employees could have "rolled their own" portfolios to mimic the age-relevant target-date fund mix using funds available prior to the inclusion of the targetdate funds on the menu.
} 
likely lower bound estimates of the effects of target-date funds on portfolio returns under normal market conditions.

Table 7 here

The middle section of Table 7 reports how expected portfolio volatility levels changed when participants switched to target-date funds. For pure investors younger than age 35, annualized volatility measures rose by 3 percentage points; for pure investors over age 55, they remained essentially unchanged. The final section of Table 7 indicates how portfolio nonsystematic risk shares changed for participants choosing the funds. Not surprisingly, there was a substantial reduction in nonsystematic risk for pure target-date fund investors as their contributions switched to all-indexed target-date funds. This accounted for 39 percentage points of total variance before target-date funds; the marginal effect of shifting to target-date funds was a negative 25 percentage points. The NSR share fell more for younger pure investors (-32 percentage points) than for older participants (-24 percentage points), and changes for mixed target-date fund investors were smaller.

\section{Conclusions and Discussion}

Since 401(k) plans were first introduced in the US in 1981, one of their distinguishing features has been a reliance on individual investment choice - that is, employers assumed fiduciary responsibility for selecting fund offerings within 401(k) plans, but individual workers remained responsible for portfolio decisions. But research on financial literacy and behavioral biases in decision-making have raised concerns that some employees may be unable to make effective portfolio choices, thus potentially undermining their old-age financial security. One way in which the retirement marketplace has attempted to address this concern has been the introduction of target-date funds to 401(k) plans. These target-date funds offer three distinct features: a convenience or "prepackaged” aspect, a current portfolio choice based on a simplified decision heuristic (expected retirement age), and a commitment device for future age-based equity rebalancing.

Through the growing incidence of these funds, responsibility for portfolio decisionmaking has begun to shift away from workers and back to employer. Demand for target-date funds has been influenced by two mechanisms: a complex default architecture, developed by 
employers and encouraged by the QDIA regulations of the U.S. Department of Labor, and active choice by participants and reliance on the funds as a form of implicit lifecycle advice.

We seek to disentangle the effects of this complex choice environment using data from a natural experiment, namely the introduction and evolution of target-date funds among 401(k) plans over the 2003-10 period. Our analysis considers both adoption patterns, influenced by default arrangements or participant active choice, as well as portfolio effects among participants actively selecting the funds upon their first appearance in the plan menu. In terms of adoption, in some plans, participants chose the funds based on their own decisions unaffected by any default arrangement. In others, employers designated the target-date funds as a default investment for recordkeeping purposes, for new hire automatic enrollment, for reenrollment from a prior default fund, for mapping of discontinued funds, or some combination of these. We show that understanding how target-date funds change investor outcomes when added to a plan menu depends substantively on the choice architecture in place at the time of their introduction. Moreover, ascertaining whether participants who actively choose target-date funds are doing so on account of the funds' glide paths requires controlling for unobservable characteristics that might influence their adoption, as well as workers’ preexisting taste for pre-packaged solutions. Our difference-in-difference empirical approach addresses these concerns.

We have three broad findings. First, there is a latent demand for target-date funds among workers based on voluntary choice and this is independent of default effects. New plan entrants adopted these funds voluntarily at a (time-weighted) average rate of 31 percent over the 2003-10 period; existing employees' take-up rate was roughly half that level. Demand was particularly strong among workers early in the lifecycle. Participants electing target-date funds on their own, rather than being defaulted or mapped into them, were equally likely to be pure target-date versus mixed target-date fund investors. In other words, preferences for the features of targetdate funds among those making voluntary decisions were not simply a binary, all-or-nothing choice. Demand for such funds was also quite resilient to equity market conditions, since active adoption of target-date funds increased somewhat during the recent financial crisis.

Second, default constructs had a potent effect on portfolio outcomes, although the magnitude depended on the exact features of the default arrangement. The simple designation of a target-date fund series as a default for administrative or recordkeeping purposes - where employees were not directly placed in the new funds - had a "halo" effect on participant 
outcomes: new plan entrants were 55 percent more likely to hold the funds compared to nondefaulted new entrants. As expected from prior research, automatic enrollment of new hires did raise target-date adoption: they were 81 percent more likely to elect these funds, compared to an “unguided” outcome. When employers reenrolled participants from a prior default to new targetdate default funds, adoption rates also rose by a similar amount, up 71 percent among new entrants. When employers eliminated a fund from the menu and "mapped” participants into target-date funds, target-date adoption rose by 166 percent among new entrants, and more than doubled among existing employees.

Third, among participants actively switching to target-date funds when they were first introduced, a difference-in-difference analysis confirms that the introduction of the funds in the plan menu resulted in sizeable changes in portfolio characteristics. Particularly notable was the large steepening of the age-equity allocation gradient, with workers younger than age 35 experiencing a 40 percent point rise in equity share; participants age 35-55 experiencing a 21 percent point increase; and no change seen for participants age 55+. Nonsystematic risk shares also fell markedly for target-date investors of all ages. Further, we showed that systematic returns and portfolio variance increased, particularly for younger investors. These changes in portfolio characteristics occurred as a result of the introduction of target-date funds by the employer, despite the fact that participants could have adopted these changes on their own before the target-date funds appeared.

These effects provide evidence of participant demand for employer-selected investment advice implicit in the funds' glide paths (with the term "advice” here used in a practical, rather than a legal sense). Our findings are robust to controls for default effects, observable plan and participant differences, pre-existing tastes for prepackaged investment programs, and unobservable individual characteristics. ${ }^{33}$ We conclude that responsibility for portfolio decisions is gradually shifting away from workers to employers through the growth of target-date funds in 401(k) plans. In default arrangements, this effect is direct: account contributions are invested in target-date funds at the explicit direction of the employer. When participants actively choose the funds, this effect is indirect: many participants adopt quite different allocations in response to the

\footnotetext{
${ }^{33}$ Thus far we cannot determine whether this was mainly due to workers favoring the simplified decision heuristic (expected retirement age) associated with the current portfolio choice, or a preference for the commitment device for future age-based rebalancing, or some combination of both.
} 
introduction of the target-date equity glide paths into the plan menu. Regardless of the decisionmaking mechanism, many retirement plan investors appear to have malleable or ambiguous preferences for portfolio choice, because of lack of financial knowledge and experience, behavioral biases, or other reasons.

Our results also have implications for household finance more broadly. Households seem particularly willing to rely on default or simplified advice arrangements when facing complex and consequential financial choices. Inertia, too, is a dominant heuristic, not only in saving behavior but in portfolio allocation decisions. Policy prescriptions in such instances might include not only default arrangements, but also programs or services that offer simplifying choices and/or embedded advice. An important question for future research is whether such design principles can also inform household decisions of consequence in other domains, including the choice of health insurance plans, taxable saving and investments, mortgage instruments, and insurance.

\section{References}

Agnew, Julie, Pierluigi Balduzzi, and Annika Sunden. 2003. "Portfolio Choice and Trading in a Large 401(k) Plan,” American Economic Review, 93(1): 193-215.

Agnew, Julie, Lisa Szykman, Stephen P. Utkus and Jean A. Young. 2011. "What People Know About Target-Date Funds: Survey and Focus Group Evidence.” CRR Working Paper.

Ameriks, John, Dean J. Hamilton and Liqian Ren. 2011. "Investor comprehension and usage of targetdate funds: 2010 survey.” Vanguard Investment Counseling and Research, Malvern, PA.

Ameriks, John and Stephen Zeldes. 2001. “How Do Household Portfolio Shares Vary with Age?” TIAA-CREF Institute Working Paper 6-120101.

Barber, Brad and Terry Odean. 2001. "Boys will be Boys: Gender, Overconfidence, and Common Stock Investment,” Quarterly Journal of Economics. 116(1): 261-292.

Benartzi, Shlomo. 2001. "Excessive Extrapolation and the Allocation of 401(k) Accounts to Company Stock.” Journal of Finance. October. 56(5): 1747-1764.

Benartzi, Shlomo and Richard H. Thaler. 2001. "Naïve Diversification Strategies in Defined Contribution Savings Plans.” American Economic Review. March. 91(1): 79-98.

Benartzi, Shlomo and Richard H. Thaler. 2002. "How Much Is Investor Autonomy Worth?" Journal of Finance. August. 57(4): 1593-1616.

Benartzi, Shlomo, Ehud Peleg, and Richard H. Thaler. 2007. "Choice Architecture and Retirement Savings Plans.” SSRN Working Paper. July. 
Brown, Jeffrey R., Nellie Lang and Scott Weisbenner. 2007. "Individual Account Investment Options and Portfolio Choice: Behavioral Lessons from 401(k) Plans.” Journal of Public Economics. 91(10): $1992-2013$.

Calvet, Laurent E., John Y. Campbell, and Paolo Sodini. 2009. “Fight or Flight? Portfolio Rebalancing by Individual Investors.” Quarterly Journal of Economics. 124: 301-348.

Carroll, Gabriel D., James J. Choi, David Laibson, Brigitte C. Madrian, and Andrew Metrick. 2009. “Optimal Defaults and Active Decisions.” Quarterly Journal of Economics 124(4): 1639-1674.

Choi, James J., David Laibson, and Brigitte C. Madrian. 2004. "Plan Design and 401(k) Savings Outcomes." National Tax Journal. 57 (2): 275-298.

Choi, James J., David Laibson, Brigitte C. Madrian, and Andrew Metrick. 2003. "Optimal Defaults." American Economic Review. 93 (2): 180-185.

Choi, James J., David Laibson, Brigitte C. Madrian, and Andrew Metrick. 2006. “Saving for Retirement on the Path of Least Resistance.” In Behavioral Public Finance: Toward a New Agenda, Ed McCaffrey and Joel Slemrod, eds. New York: Russell Sage Foundation: 304-351.

Copeland, Craig. 2011. “Target-Date Fund Use in 401(k) Plans and the Persistence of their Use 20072009.” Washington: Employee Benefits Research Institute. Issue Brief No. 361, August.

Holden, Sarah, Jack VanDerhei, Luis Alonso, and Steven Bass. 2011. “401(k) Plan Asset Allocation, Account Balances, and Loan Activity in 2010.” ICI Research Perspective 17, no. 10 (December).

Huberman, Gur and Wei Jiang. 2006. "Offering vs. Choices in 401(k) Plans: Equity Exposure and Number of Funds.” Journal of Finance. 41 (2): 763-801.

ICI, 2011. 2011 Investment Company Fact Book. 51 $1^{\text {st }}$ edition. Washington, DC.: Investment Company Institute.

Iyengar, Sheena, Gur Huberman and Wei Jiang. 2004. "How Much Choice is Too Much? Contributions to 401(k) Retirement Plans.” In Pension Design and Structure: New Lessons from Behavioral Finance, Olivia S. Mitchell and Stephen P. Utkus, eds. Oxford: Oxford University Press: 83-96.

Iyengar, Sheena, and Emir Kamenica. 2010. "Choice Proliferation, Simplicity Seeking and Asset Allocation.” Journal of Public Economics. 94(7-8). 530-539.

Lusardi, Annamaria and Olivia S. Mitchell. 2007. "Baby Boomer Retirement Security: The Role of Planning, Financial Literacy and Housing Health. Journal of Monetary Economics. 54(1) January: 205-224.

Lusardi, Annamaria and Olivia S. Mitchell. 2011. "Financial Literacy and Retirement Planning in the United States.” Journal of Pension Economics \& Finance. 10(4): 509-525.

Madrian, Brigitte, and D.F. Shea. 2001. “The Power of Suggestion: Inertia in 401(k) Participation and Savings Behavior.” Quarterly Journal of Economics 116 (4 ): 1149-1525. 
Mitchell, Olivia S. and Annamaria Lusardi, eds. 2011. Financial Literacy: Implications for Retirement Security and the Financial Marketplace. Oxford: Oxford University Press.

Mitchell, Olivia S., Gary R. Mottola, Stephen P. Utkus, and Takeshi Yamaguchi. 2006a. "The Inattentive Participant: Portfolio Trading Behavior in 401(k) Plans.” Pension Research Council Working Paper 2006-05. Philadelphia, PA.: Wharton School.

Mitchell, Olivia S., Gary R. Mottola, Stephen P. Utkus and Takeshi Yamaguchi. 2006b. "Winners and Losers: 401(k) Trading and Portfolio Performance.” Pension Research Council Working Paper 2006-26. Philadelphia, PA.: Wharton School.

Mottola, Gary R. and Stephen P. Utkus. 2008. "Red, Yellow and Green: Measuring the Quality of 401(k) Portfolio Choices.” In Overcoming the Savings Slump: How to Increase the Effectiveness of Financial Education and Saving Programs, Annamaria Lusardi, ed. Chicago: University of Chicago Press: 199-139.

Mottola, Gary R. and Stephen P. Utkus. 2009. "Reenrollment and Target-date Funds: A Case Study in Portfolio Reconstruction.” Vanguard Center for Retirement Research, Malvern, PA.

Nessmith, William E., Stephen P. Utkus, and Jean A. Young. 2007. "Measuring the Effectiveness of Automatic Enrollment." Vanguard Center for Retirement Research, Malvern, PA.

O’Donoghue, Ted, and Matthew Rabin. 1999. “Procrastination in Preparing for Retirement.” In Henry Aaron, ed., Behavioral Dimensions of Retirement Economics. Washington, D.C.: Brookings Institution Press and Russell Sage Foundation: 125-156.

O’Donoghue, Ted, and Matthew Rabin. 2001. “Choice and Procrastination.” Quarterly Journal of Economics. 116(1): 121-160.

Pagliaro, Cynthia A. and Stephen P. Utkus. 2011. "Mixed target-date investors in defined contribution plans.” Malvern: Vanguard Center for Retirement Research.

Park, Youngkyun. 2009. "Investment Behavior of Target-Date Fund Users Having Other Funds in 401(k) Accounts.” EBRI Notes. 30(12). Washington: Employee Benefits Research Institute.

Samwick, Andrew A., and Jonathan Skinner. 2004. "How Will 401(k) Pension Plans Affect Retirement Income?" American Economic Review, 94(1): 329-343.

Tang, Ning, Olivia S. Mitchell, Gary R. Mottola, and Stephen P. Utkus. 2010. “The Efficiency of Sponsor and Participant Portfolio Choices in 401(k) Plans.” Journal of Public Economics. 94(11-12): 1073-1085.

Thaler, Richard and Cass Sunstein. 2008. Nudge: Improving Decisions About Health, Wealth, and Happiness. New Haven: Yale University Press.

Vanguard. 2008. Improving Plan Diversification Through Reenrollment in a QDIA. Malvern: Vanguard Strategic Retirement Consulting. institutional.vanguard.com. 
Vanguard, 2011. How America Saves 2011: A Report on Vanguard 2010 Defined Contribution Plan Data. Malvern: Vanguard Center for Retirement Research. 
Table 1. Target-Date Fund Characteristics

\section{A. Portfolio Allocation for Target-Date Funds by Specified Target Year}

\begin{tabular}{c|ccccc}
\hline & & & \multicolumn{3}{c}{$\begin{array}{c}\text { U.S. inflation- } \\
\text { protected }\end{array}$} \\
Date of Fund & $\begin{array}{c}\text { U.S. } \\
\text { stocks } \\
\mathbf{( \% )}\end{array}$ & $\begin{array}{c}\text { Non-U.S. } \\
\text { stocks (\%) }\end{array}$ & $\begin{array}{c}\text { U.S. nominal } \\
\text { bonds (\%) }\end{array}$ & $\begin{array}{c}\text { bonds (\%) } \\
\text { Cash (\%) }\end{array}$ & Co. \\
\hline 2055 & 63.0 & 27.0 & 10.0 & 0.0 & 0.0 \\
2050 & 63.0 & 27.0 & 10.0 & 0.0 & 0.0 \\
2045 & 63.0 & 27.0 & 10.0 & 0.0 & 0.0 \\
2040 & 63.0 & 27.0 & 10.0 & 0.0 & 0.0 \\
2035 & 62.5 & 26.8 & 10.8 & 0.0 & 0.0 \\
2030 & 57.2 & 24.5 & 18.3 & 0.0 & 0.0 \\
2025 & 52.0 & 22.3 & 25.8 & 0.0 & 0.0 \\
2020 & 46.7 & 20.0 & 33.3 & 0.0 & 0.0 \\
2015 & 41.3 & 17.7 & 40.0 & 1.0 & 0.0 \\
2010 & 34.0 & 14.6 & 40.4 & 10.7 & 0.4 \\
2005 & 24.0 & 10.3 & 43.9 & 17.9 & 3.9 \\
Income & 21.0 & 9.0 & 45.0 & 20.0 & 5.0 \\
\hline
\end{tabular}

Note: As of December 31, 2010.

\section{B. Introduction of Target-Date Funds to 401(k) Plans}

\begin{tabular}{|c|c|c|c|c|c|c|}
\hline & \multicolumn{4}{|c|}{ Full sample } & \multirow{2}{*}{\multicolumn{2}{|c|}{\begin{tabular}{|c|}
$\begin{array}{c}\text { Diffe rence-in-difference } \\
\text { sample }\end{array}$ \\
Target-date fund adopters \\
\end{tabular}}} \\
\hline & \multicolumn{2}{|c|}{ Plans } & \multicolumn{2}{|c|}{ Accounts } & & \\
\hline & $\mathrm{N}$ & $\%$ & $\mathrm{~N}^{*}$ & $\%$ & $\mathrm{~N}^{* *}$ & $\%$ \\
\hline $\begin{array}{l}\text { Plan introduced target-date funds de } \\
\text { novo }\end{array}$ & 475 & 47 & $1,058,189$ & 48 & 39,550 & 24 \\
\hline $\begin{array}{l}\text { Plan added target-date funds to static } \\
\text { allocation (SA) funds }\end{array}$ & 211 & 21 & 509,740 & 23 & 8,666 & 5 \\
\hline $\begin{array}{l}\text { Plan switched from static allocation (SA) } \\
\text { funds to target-date funds }\end{array}$ & 322 & 32 & 634,482 & 29 & 115,220 & 71 \\
\hline Total & 1,008 & & $2,202,411$ & & 163,436 & \\
\hline
\end{tabular}

Notes:

*Unique accounts over the 2003-2010 period in the full sample, including target-date non-adopters and adopters;

**Unique target-date adopter accounts over the 2003-2010 period in the difference-in-difference sample.

Source: Authors’ tabulations. 
Table 2. Descriptive Characteristics: Plans and Participants

\begin{tabular}{|c|c|c|c|c|c|c|}
\hline & \multicolumn{3}{|c|}{ Full sample } & \multicolumn{3}{|c|}{$\begin{array}{c}\begin{array}{c}\text { Difference-in-diffe rence } \\
\text { sample }\end{array} \\
\end{array}$} \\
\hline & All & $\begin{array}{l}\text { Pure TDF } \\
\text { Investors }\end{array}$ & $\begin{array}{c}\text { Mixed TDF } \\
\text { Investors } \\
\end{array}$ & $\begin{array}{l}\text { All TDF } \\
\text { Investors }\end{array}$ & $\begin{array}{c}\text { Pure } \\
\text { Investors }\end{array}$ & $\begin{array}{c}\text { Mixed TDF } \\
\text { Investors } \\
\end{array}$ \\
\hline \multicolumn{7}{|l|}{ Default architecture (\%) } \\
\hline Default & 80.1 & 91.3 & 85.9 & 61.9 & 67.4 & 57.8 \\
\hline New-hire auto enrollment & 48.3 & 60.5 & 45.2 & 40.4 & 53.7 & 30.6 \\
\hline Reenrollment & 1.5 & 3.9 & 0.2 & 2.9 & 6.6 & 0.1 \\
\hline Mapping & 4.4 & 5.2 & 17.9 & 24.9 & 18.1 & 29.9 \\
\hline \multicolumn{7}{|l|}{ Other plan features (\%) } \\
\hline N Funds offered (mean) & 28.7 & 28.4 & 25.7 & 23.8 & 23.5 & 24.0 \\
\hline Employer stock offered & 45.0 & 42.1 & 56.1 & 50.8 & 39.4 & 59.2 \\
\hline Loan offered & 85.5 & 85.1 & 92.5 & 90.0 & 85.2 & 93.4 \\
\hline SA_before & 52.0 & 57.5 & 53.7 & 75.8 & 78.4 & 73.9 \\
\hline \multicolumn{7}{|l|}{ Participant characteristics } \\
\hline Log balance (mean 2010\$) & 9.7 & 8.4 & 10.2 & 10.2 & 9.7 & 10.5 \\
\hline New entrants (\%) & 42.6 & 78.3 & 42.7 & N/A & N/A & N/A \\
\hline Job tenure (years) & 9.4 & 5.1 & 9.1 & 8.6 & 7.3 & 9.5 \\
\hline Young $(<35, \%)$ & 25.3 & 39.3 & 26.1 & 28.7 & 33.4 & 25.3 \\
\hline Middle (35-55, \%) & 55.4 & 49.0 & 57.8 & 57.6 & 53.3 & 60.8 \\
\hline Old $(>55, \%)$ & 19.2 & 11.6 & 16.1 & 13.7 & 13.3 & 14.0 \\
\hline Male (\%) & 56.2 & 54.0 & 57.8 & 53.1 & 50.0 & 55.3 \\
\hline HH income low $(<\$ 62.5 \mathrm{~K}, \%)$ & 21.7 & 22.9 & 19.4 & 21.9 & 25.3 & 19.4 \\
\hline HH income medium ( $\$ 62.5-\$ 87.5 \mathrm{~K}, \%)$ & 39.9 & 50.2 & 37.5 & 39.0 & 41.0 & 37.5 \\
\hline HH income high $(>\$ 87.5 \mathrm{~K})$ & 38.4 & 26.8 & 43.1 & 39.1 & 33.7 & 43.1 \\
\hline \multicolumn{7}{|l|}{ Non-ret. financial we alth } \\
\hline Low $(<\$ 7.3 \mathrm{~K}, \%)$ & 43.5 & 50.7 & 41.2 & 45.1 & 49.2 & 42.1 \\
\hline Average (\$7.3K-\$61.2K, \%) & 35.5 & 33.5 & 37.2 & 35.6 & 33.8 & 37.0 \\
\hline High $(>\$ 61.2 \mathrm{~K}, \%)$ & 21.0 & 15.8 & 21.6 & 19.3 & 17.1 & 20.9 \\
\hline \multicolumn{7}{|l|}{ Financial crisis } \\
\hline Financial crisis (\% of year) & 5.7 & 6.1 & 5.3 & 15.1 & 20.3 & 11.3 \\
\hline \multicolumn{7}{|l|}{ TDF adoption (account \%) } \\
\hline TDF investor & 41.4 & 100.0 & 100.0 & 100.0 & 100.0 & 100.0 \\
\hline Pure TDF investor & 29.6 & 100.0 & 0.0 & 42.3 & 100.0 & 0.0 \\
\hline Mixed TDF investor & 11.8 & 0.0 & 100.0 & 57.7 & 0.0 & 100.0 \\
\hline \multicolumn{7}{|l|}{ Observations } \\
\hline $\mathrm{N}$ plans & 1,008 & 996 & 982 & 940 & 857 & 849 \\
\hline $\mathrm{N}$ accounts & $2,202,411$ & 651,396 & 259,393 & 163,436 & 69,148 & 94,288 \\
\hline
\end{tabular}

Note: For the 2003-2010 summary of the full sample, characteristics are measured as of the final contribution date between 2003 and 2010, including new entrants. For the difference-in-difference sample, characteristics are measured six months after target-date fund introduction. Each observation represents one account.

See text for variable definitions.

Source: Authors' tabulations. 
Table 3. Determinants of Participant Target-Date Fund Adoption Patterns (full sample)

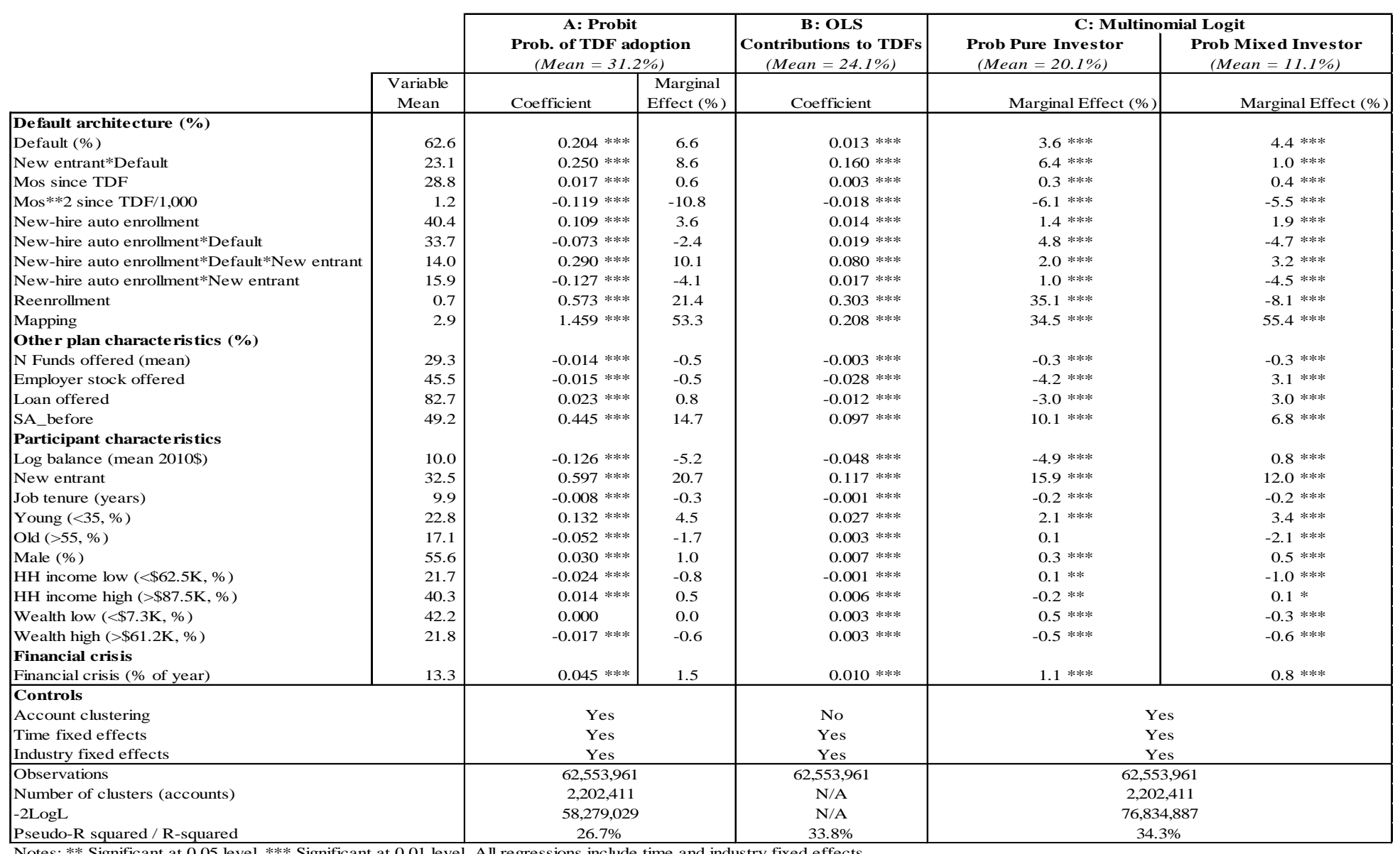

Probit and logit models include clustered standard errors at the account level. For variable definitions see text. Source: Authors' computations. 
Table 4. Plan Choice Architecture: Summary of Predicted Effects on Employee Outcomes (full sample)
(1)
(2)
(3)
(4)

\begin{tabular}{|c|c|c|c|c|}
\hline & $\begin{array}{l}\text { Prob. of TDF } \\
\text { adoption (\%) }\end{array}$ & $\begin{array}{c}\text { Total } \\
\text { Contributions } \\
\text { to TDF } \\
\end{array}$ & $\begin{array}{c}\text { Prob. of Pure } \\
\text { TDF (\%) } \\
\end{array}$ & $\begin{array}{c}\text { Prob of } \\
\text { Mixed TDF } \\
(\%)\end{array}$ \\
\hline mple mean & 31.2 & 24.1 & 20.1 & 11.1 \\
\hline \multicolumn{5}{|l|}{ Active choice } \\
\hline A. New entrants & 31.4 & 24.0 & 15.9 & 16.9 \\
\hline B. Existing participants & 14.0 & 12.3 & 5.6 & 6.9 \\
\hline \multicolumn{5}{|l|}{ Indirect default } \\
\hline A. New entrants & 48.8 & 41.3 & 29.9 & 26.0 \\
\hline B. Existing participants & 19.0 & 13.6 & 7.5 & 10.4 \\
\hline
\end{tabular}

III. Direct default to target-date fund
A. New entrants
B. Existing participants

56.7

54.3

47.7

17.3

IV. Reenrollment to target-date fund
A. New entrants
53.6
54.4
65.6
6.0
B. Existing participants
30.6
42.6
33.0
3.2

V. Mapping to target-date fund
A. New entrants
83.5
44.8
53.5
76.6
B. Existing participants
64.7
33.1
26.4
54.6

Source: Predicted effects derived from models in Tables 3 (probability of adoption, employee contributions, and pure versus mixed TDF adopters). "New entrants" are participants who enrolled with TDFs offered in the investment menu; "existing participants" are participants who enrolled prior to TDFs being introduced in the menu. For definitions of default categories, see text.

Source: Authors' computations. 
Table 5. Pre/Post Contribution Allocations and Portfolio Characteristics (Difference-in-difference sample)

A. Contribution Allocation (\%)

\begin{tabular}{llrrrrrr}
\hline & & & & Balanced/ & \multicolumn{2}{c}{ U.S. International } & Company \\
& & Cash & Bonds & TDF & Equities & Equities & Stock \\
\hline All TDF & Pre & 14.5 & 6.5 & 42.1 & 26.4 & 5.3 & 5.3 \\
investors & Post & 4.0 & 4.0 & 63.6 & 20.1 & 5.0 & 3.3 \\
& Change & -10.6 & -2.5 & 21.5 & -6.3 & -0.2 & -2.0 \\
\cline { 2 - 8 } Pure TDF & Pre & 21.8 & 5.7 & 57.6 & 12.0 & 1.4 & 1.5 \\
investors & Post & 0.0 & 0.0 & 100.0 & 0.0 & 0.0 & 0.0 \\
& Change & -21.8 & -5.7 & 42.4 & -12.0 & -1.4 & -1.5 \\
Mixed TDF & Pre & 9.2 & 7.2 & 30.7 & 36.9 & 8.0 & 8.0 \\
investors & Post & 6.9 & 7.0 & 36.9 & 34.8 & 8.7 & 5.7 \\
& Change & -2.3 & -0.1 & 6.2 & -2.0 & 0.6 & -2.3 \\
\hline
\end{tabular}

B. Portfolio Risk/Return Characteristics (\%)

\begin{tabular}{llrrrr}
\hline & & $\begin{array}{r}\text { Equity } \\
\text { Allocations }\end{array}$ & $\begin{array}{r}\text { Systematic } \\
\text { Returns }\end{array}$ & $\begin{array}{r}\text { Portfolio } \\
\text { risk ( } \mathbf{\sigma})\end{array}$ & NSR/TV \\
\hline All TDF & Pre & 62.5 & 5.84 & 0.11 & 31.7 \\
investors & Post & 75.8 & 6.32 & 0.12 & 12.2 \\
& Change & 13.4 & 0.48 & 0.01 & -19.5 \\
\cline { 2 - 6 } Pure TDF & Pre & 49.5 & 5.69 & 0.09 & 38.9 \\
investors & Post & 75.1 & 6.54 & 0.12 & 5.5 \\
& Change & 25.7 & 0.86 & 0.03 & -33.3 \\
Mixed TDF & Pre & 72.0 & 5.94 & 0.12 & 26.5 \\
investors & Post & 76.3 & 6.16 & 0.13 & 17.1 \\
& Change & 4.4 & 0.21 & 0.01 & -9.4 \\
\hline
\end{tabular}

Source: Authors’ computations. 
Table 6. Determinants of the Share of Participant Portfolios in Equity (OLS coefficients; difference-in-difference sample)

\begin{tabular}{|c|c|c|c|c|}
\hline & \multicolumn{2}{|c|}{ Pure TDF Investors } & \multicolumn{2}{|c|}{ Mixed TDF Investors } \\
\hline & Model A & Model B & Model C & Model D \\
\hline \multicolumn{5}{|l|}{ Default architecture (\%) } \\
\hline New-hire auto enrollment & $0.014 * * *$ & $0.013 * * *$ & 0.001 & 0.000 \\
\hline Reenrollment & $0.047 * * *$ & $0.046 * * *$ & $-0.195 * * *$ & $-0.195 * * *$ \\
\hline Mapping & $0.075 * * *$ & $0.092 * * *$ & 0.001 & $0.003 *$ \\
\hline \multicolumn{5}{|l|}{ Treatment } \\
\hline TDF_treat & $0.195 * * *$ & $0.173 * * *$ & $0.042 * * *$ & $0.040 * * *$ \\
\hline TDF_treat*Young & & $0.145 * * *$ & & $0.041 * * *$ \\
\hline TDF_treat*old & & $-0.198 * * *$ & & $-0.064 * * *$ \\
\hline TDF_treat*Low_income & & $-0.009 * * *$ & & 0.000 \\
\hline TDF_treat*High_income & & $-0.037 * * *$ & & $-0.006 * * *$ \\
\hline TDF_treat*Male & & $0.005 * * *$ & & $-0.003 * * *$ \\
\hline TDF_treat*Poor_wealth & & $0.026 * * *$ & & $0.006 * * *$ \\
\hline TDF_treat*Rich_wealth & & $-0.017 * * *$ & & $0.006 * * *$ \\
\hline \multicolumn{5}{|l|}{ Other plan features (\%) } \\
\hline N funds offered (mean) & $-0.001 * * *$ & $-0.001 * * *$ & $0.000 * *$ & 0.000 \\
\hline Employer stock offered & $-0.088 * * *$ & $-0.089 * * *$ & $0.037 * * *$ & $0.037 * * *$ \\
\hline Loan offered & $0.073 * * *$ & $0.073 * * *$ & 0.004 & 0.004 \\
\hline SA_before & $0.005 * * *$ & $0.004 * *$ & $0.027 * * *$ & $0.026 * * *$ \\
\hline \multicolumn{5}{|l|}{ Participant characteris tics } \\
\hline Log balance (mean 2010\$) & $0.019 * * *$ & $0.017 * * *$ & $0.023 * * *$ & $0.023 * * *$ \\
\hline Job tenure (years) & $-0.001 * * *$ & $-0.001 * * *$ & $-0.003 * * *$ & $-0.003 * * *$ \\
\hline Young $(<35, \%)$ & $0.028 * * *$ & $-0.044 * * *$ & $0.034 * * *$ & $0.014 * * *$ \\
\hline Old (>55, \%) & $-0.106 * * *$ & -0.001 & $-0.094 * * *$ & $-0.061 * * *$ \\
\hline Male (\%) & $0.003 * *$ & 0.002 & $0.025 * * *$ & $0.026 * * *$ \\
\hline $\mathrm{HH}$ income low $(<\$ 62.5 \mathrm{~K}, \%)$ & $-0.005 * * *$ & 0.000 & $-0.012 * * *$ & $-0.012 * * *$ \\
\hline $\mathrm{HH}$ income high (>\$87.5K, \%) & -0.002 & $0.019 * * *$ & $0.005 * * *$ & $0.008 * * *$ \\
\hline Wealth low (<\$7.3K, \%) & $-0.003 * * *$ & $-0.017 * * *$ & $-0.009 * * *$ & $-0.012 * * *$ \\
\hline Wealth high (>\$61.2K, \%) & -0.001 & $0.008 * * *$ & $0.003 *$ & 0.000 \\
\hline \multicolumn{5}{|l|}{ Financial cris is } \\
\hline Financial crisis (\% of year) & $0.159 * * *$ & $0.138 * * *$ & $0.040 * * *$ & $0.037 * * *$ \\
\hline \multicolumn{5}{|l|}{ Controls } \\
\hline Account level cluster & \multicolumn{4}{|c|}{ Yes } \\
\hline Time fixed effects & \multicolumn{4}{|c|}{ Yes } \\
\hline Industry fixed effects & \multicolumn{4}{|c|}{ Yes } \\
\hline Observations & 138,296 & 138,296 & 188,576 & 188,576 \\
\hline Accounts & 69,148 & 69,148 & 94,288 & 94,288 \\
\hline $\mathrm{R}$ squared & $41.7 \%$ & $46.5 \%$ & $9.2 \%$ & $9.8 \%$ \\
\hline \multicolumn{5}{|l|}{ Dependent means } \\
\hline Pre-treat & \multicolumn{2}{|c|}{$49.5 \%$} & \multicolumn{2}{|c|}{$72.0 \%$} \\
\hline Post-treat & \multicolumn{2}{|c|}{$75.1 \%$} & \multicolumn{2}{|c|}{$76.3 \%$} \\
\hline Unadjusted difference & \multicolumn{2}{|c|}{$25.6 \%$} & \multicolumn{2}{|c|}{$4.4 \%$} \\
\hline
\end{tabular}

Note: Separate OLS difference-in-difference models for pure versus mixed adopters.

Independent variable characteristics are described in Table 2; dependent variable means are as shown at bottom of each column. Models include account-level clustering and time and industry fixed effects. ** Significant at 0.05 level, *** Significant at 0.01 level.

Source: Authors' computations. 
Table 7. Marginal Effects of Portfolio Characteristics and Target-Date Fund Treatment (OLS ; difference-in-difference sample)

\begin{tabular}{|c|c|c|c|c|c|c|c|c|c|c|c|c|}
\hline & \multicolumn{4}{|c|}{$\begin{array}{l}\text { Annualized returns } \\
\end{array}$} & \multicolumn{4}{|c|}{ Annualized standard deviation (o) } & \multicolumn{4}{|c|}{ Nonsystematic risk/Total variance (NSR/TV) } \\
\hline & \multicolumn{2}{|c|}{ Pure TDF Investors } & \multicolumn{2}{|c|}{ Mixed TDF Investors } & \multicolumn{2}{|c|}{ Pure TDF Investors } & \multicolumn{2}{|c|}{ Mixed TDF Investors } & \multicolumn{2}{|c|}{ Pure TDF Investors } & \multirow{2}{*}{\multicolumn{2}{|c|}{ Mixed TDF Investors }} \\
\hline & Model A & Model B & Model C & Model D & \begin{tabular}{l|l} 
Model A \\
\end{tabular} & Model B & Model C & Model D & Model A & Model B & 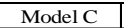 & \\
\hline \multicolumn{11}{|l|}{ efault archite } & & \\
\hline & $053 * * * \mid$ & $0.0052 * * *$ & $0.0011 * * *$ & $0.0011 * * *$ & $029 * * * *$ & $0.0030 * * *$ & $-0.0012 * * * \mid$ & $-0.0012 * * *$ & $-0.2069 * * * \mid$ & $-0.2065 * * *$ & $0.0275 * * *$ & $0.0269 * * *$ \\
\hline Reenrollment & $0.0017 * * *$ & $0.0017 * * *$ & $-0.0095 * * *$ & $|-0.0095 * * *|$ & $0.0043 * * *$ & $0.0041 * * *$ & $-0.0320 * * * \mid$ & $-0.0320 * * *$ & $-0.0766 * * * \mid$ & $|-0.0763 * * *|$ & $0.1714 * * *$ & $0.1719 * * *$ \\
\hline $\begin{array}{l}\text { Mapping } \\
\text { Treatment }\end{array}$ & $0.0014 * * *$ & $0.0016^{* * *}$ & $0.0021 * * *$ & $0.0021 * * *$ & $-0.0025 * * *$ & $-0.0008 * * *$ & $0.0034^{* * * *}$ & $0.0035 * * *$ & $-0.0454 * * * \mid$ & $-0.0507^{* * * *}$ & $-0.0386 * * *$ & $-0.0406 * * *$ \\
\hline rDF_treat & $0.0065 * * *$ & $0.0068 * * *$ & $0.0022 * * *$ & $0.0026 * * *$ & $0.0201 * * *$ & $0.0136 * * *$ & $0.0081 * * *$ & $0.0079 * * * *$ & $-0.2450 * * * \mid$ & $-0.2363 * * * \mid$ & $-0.0831 * * *$ & {$[-0.0582 *$} \\
\hline $\mathrm{t} *$ Young & & $0.0023 * * *$ & & $0.0004 * * *$ & & $0.0179 * * *$ & & $0.0034 * * * *$ & & $-0.0860 * * * \mid$ & & -0 \\
\hline *Old & & $-0.0022 * * *$ & & $-0.0008 * * *$ & & $-0.0135 * * * *$ & & $-0.0041 * * * *$ & & -0.0016 & & \\
\hline & & $-0.0002 * *$ & & $-0.0002 * * *$ & & $0.0027 * * *$ & & 0.0000 & & $0.0223 * * *$ & & $-0.0074 *$ \\
\hline & & $-0.0007 * * *$ & & $-0.0005 * * *$ & & $-0.0039 * * *$ & & $-0.0011 * * *$ & & $0.0440 * * *$ & & $0.0113 * *$ \\
\hline & & $-0.0005 * * *$ & & $-0.0001 * * *$ & & $0.0024 * * *$ & & $-0.0002 * * *$ & & $0.0064 * *$ & & $-0.0128 * * *$ \\
\hline CDF & & $0.0005 * * *$ & & -0.0001 & & $0.0032 * * *$ & & $0.0009 * * *$ & & $-0.0181 * * *$ & & $-0.0155 * * * *$ \\
\hline & & $-0.0004 * * *$ & & $0.0002 * *$ & & $-0.0017 * * *$ & & 0.0003 & & -0.0022 & & -0.0036 \\
\hline & $0.0015 * * *$ & 0.0001 & $0.0013 * * *$ & & $0.0069 * * *$ & $-0.0034 * * *$ & $0.0054 * * * *$ & $0.0036 * * *$ & -0.0022 & $0.0495 * * *$ & $0.0969 * * *$ & $0.1049 * * *$ \\
\hline \multirow{2}{*}{\multicolumn{13}{|c|}{\begin{tabular}{l|l|l|l}
$-0.0114 * * *$ & $-0.0036 * * *$ & $-0.0051 * * *$ \\
\end{tabular}}} \\
\hline & & & & & & & & & & & & \\
\hline $\mathrm{N}$ funds offered (mean) & $0.0000 * * *$ & $0.0000 * * *$ & $-0.0001 * * *$ & $-0.0001 * * *$ & 0.0000 & 0.0000 & $-0.0006 * * *$ & $-0.0006 * * *$ & $0.0005 * * *$ & $0.0005 * * *$ & $-0.0031 * * *$ & -0.0033 * \\
\hline Employ & $-0.0046 * * *$ & $-0.0045 * * *$ & $-0.0006 * * *$ & $-0.0006 * * *$ & $-0.0070 * * *$ & $-0.0069 * * *$ & $0.0056 * * *$ & $0.0056 * * *$ & $0.2960 * * *$ & 0.2951 & $0.1464 * * *$ & $0.1473 * * *$ \\
\hline & $0.0019 * * *$ & $0.0019 * * *$ & $-0.0019 * * *$ & $-0.0019 * * *$ & $0.0098 * * *$ & $0.0101 * * *$ & $-0.0008 *$ & -0.0007 & $-0.0631 * * *$ & $-0.0634 * * *$ & $-0.0175 * * *$ & $-0.0183 * * *$ \\
\hline \multirow{2}{*}{\multicolumn{13}{|c|}{\begin{tabular}{l|l|l|l}
$0.0045 * * *$ & $-0.1259 * * *$ & $-0.1265 * * *$ \\
\end{tabular}}} \\
\hline & & & & & & & & & & & & \\
\hline Log ba & $0.0003 * * *$ & $0.0003 * * *$ & $0.0004 * * *$ & $0.0004 * * *$ & $0.0030 * * *$ & $0.0027 * * *$ & $0.0033 * * *$ & $0.0033 * * *$ & $-0.0234 * * *$ & $|-0.0223 * * *|$ & $-0.0129 * * *$ & $-0.0124 *$ \\
\hline & $0.0000 * * *$ & $0.0000 * * *$ & $-0.0001 * * * *$ & $-0.0001 * * * *$ & $0.0000 * * *$ & 0.0000 & $-0.0004 * * * *$ & $-0.0004 * * * *$ & $-0.0005 * *$ & $-0.0006 * * * \mid$ & $-0.0004 * * * *$ & $-0.0004 * * *$ \\
\hline & $0004 * * *$ & $-0.0013 * * *$ & $0.0004 * * *$ & $0.0002 * * *$ & $0.0013 * * *$ & $-0.0063 * * *$ & $0.0044 * * *$ & $0.0029 * * *$ & $0.0472 * * *$ & $0.0839 * * *$ & $-0.0082 * * *$ & 0.0012 \\
\hline & $015 * * * *$ & $-0.0004 * * *$ & $-0.0014 * * *$ & $-0.0010 * * *$ & $-0.0117 * * *$ & $-0.0051 * * *$ & $-0.0139 * * *$ & $-0.0119 * * *$ & -0.0061 & -0.0058 & $0.0068 * *$ & $0.0149 * * *$ \\
\hline & $004 * * * *$ & $0.0006 * * *$ & $0.0008 * * *$ & $0.0008 * * *$ & $0.0013 * * *$ & 0.0001 & $0.0048 * * *$ & $0.0049 * * *$ & $-0.0185 * * *$ & $-0.0218 * * *$ & 0.0025 & $0.0089 * * *$ \\
\hline $\mathrm{HH}$ & $01 *$ & 0.0000 & $-0.0003 * * *$ & $-0.0002 * *$ & $-0.0009 * * *$ & $-0.0024 * * *$ & $-0.0014 * * * *$ & $-0.0014 * * *$ & $0.0106 * * *$ & -0.0009 & 0.0046 & $0.0083 *$ \\
\hline & 0.00 & $0.0004 * * *$ & $0.0002 * * *$ & $0.0004 * * *$ & -0.0001 & $0.0021 * * *$ & $0.0008 * * *$ & $0.0014 * * *$ & -0.0040 & $-0.0277 * * *$ & 0.0005 & -0.0055 \\
\hline Wealth low $(<\$$ & $-0.0002 * * *$ & $-0.0005 * * *$ & $-0.0004 * * *$ & $-0.0004 * * *$ & $-0.0009 * * *$ & $-0.0025 * * *$ & $-0.0018 * * *$ & $-0.0023 * * *$ & $0.0127^{* * *}$ & $0.0219 * * *$ & 0.0033 & $0.0111 * * *$ \\
\hline Wealth $\mathrm{h}$ & 0.0000 & $0.0002 *$ & $0.0001 * *$ & 0.0000 & 0.0003 & $0.0012 * *$ & $0.0007^{* * * *}$ & 0.0006 & 0.0024 & 0.0034 & $0.0049 * *$ & $0.0065 *$ \\
\hline \multirow{2}{*}{\multicolumn{13}{|c|}{$\begin{array}{l}\text { Financial crisis } \\
\text { Financial crisis (\% of year) }\end{array}$}} \\
\hline \multirow{2}{*}{\multicolumn{13}{|c|}{ Financial crisis (\% of year) }} \\
\hline & & & & & & & & & & & & \\
\hline & \multirow{2}{*}{\multicolumn{4}{|c|}{$\begin{array}{l}\text { Yes } \\
\text { Yes }\end{array}$}} & \multirow{2}{*}{\multicolumn{4}{|c|}{$\begin{array}{l}\text { Yes } \\
\text { Yes }\end{array}$}} & \multirow{2}{*}{\multicolumn{4}{|c|}{$\begin{array}{l}\text { Yes } \\
\text { Yes }\end{array}$}} \\
\hline & & & & & & & & & & & & \\
\hline Industry & \multicolumn{4}{|c|}{ Yes } & \multicolumn{4}{|c|}{ Yes } & \multicolumn{4}{|c|}{ Yes } \\
\hline & & $\overline{138,2}$ & & 188 & & 138,2 & & 188, & & & & \\
\hline & & & & & & & & & & & & \\
\hline & & $46.5 \%$ & & $8.2 \%$ & & $28.0 \%$ & & $6.7 \%$ & $3.2 \%$ & $33.4 \%$ & $1.3 \%$ & $11.4 \%$ \\
\hline is & & & & & & & & & & & & \\
\hline & & & & & 0.0 & & & & & & & \\
\hline & & & & & & & & & & & & \\
\hline Inadjus & & & & & 0.0 & 03 & & 01 & & & & \\
\hline
\end{tabular}

each column and in Table 8. Models include account-level clustering and time and industry fixed effects. ** Significant at 0.05 level, *** Significant at 0.01 level. Source: Authors' computations. 
Figure 1. Change in Participant Portfolio Equity Shares: Post Minus Pre Target-Date Fund Introduction (Difference-in-difference sample)

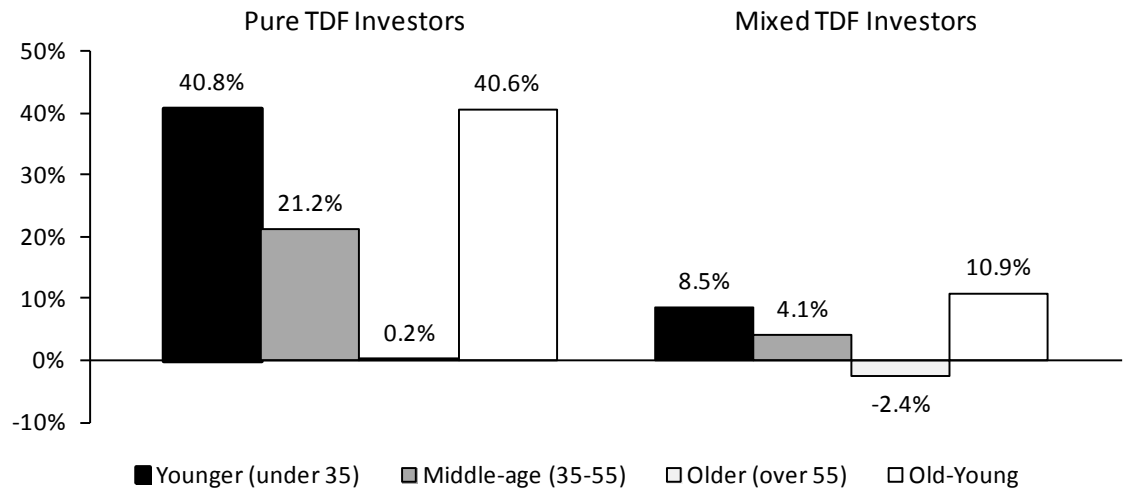

Source: Authors’ tabulations.

Figure 2. Equity Share of Participant Portfolios for Target-date Fund Investors: Pre and Post TDF Adoption (Difference-in-difference sample)
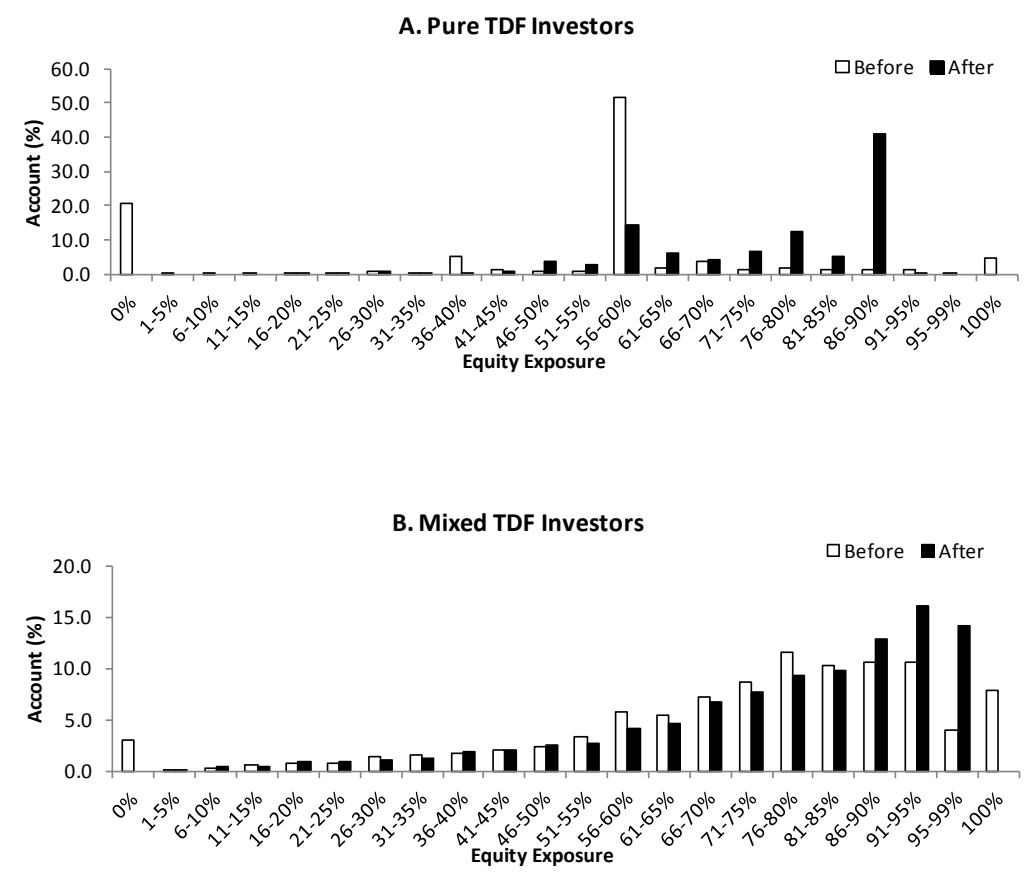

Source: Authors’ tabulations. 


\section{For Online Publication: Data Appendix: Plan and Participant Characteristics by Year and for Entire Study Period}

\section{(Full sample)}

\begin{tabular}{|c|c|c|c|c|c|c|c|c|c|}
\hline & \multicolumn{8}{|c|}{ By Year } & \multirow{2}{*}{$\begin{array}{l}\begin{array}{l}\text { Entire } \\
\text { Period }\end{array} \\
2003-10 \\
\end{array}$} \\
\hline & 2003 & 2004 & 2005 & 2006 & 2007 & 2008 & 2009 & 2010 & \\
\hline \multicolumn{10}{|l|}{ Default architecture (\%) } \\
\hline Default & 0.0 & 6.1 & 6.5 & 20.2 & 22.3 & 73.9 & 86.9 & 89.6 & 80.1 \\
\hline New-hire auto enrollment & 0.0 & 2.9 & 5.2 & 27.2 & 33.5 & 44.1 & 49.1 & 51.3 & 48.3 \\
\hline Reenrollment & 0.0 & 0.2 & 0.1 & 0.5 & 0.8 & 0.9 & 0.8 & 1.6 & 1.5 \\
\hline Mapping & 0.0 & 0.6 & 0.6 & 1.1 & 2.3 & 3.2 & 3.7 & 5.3 & 4.4 \\
\hline \multicolumn{10}{|l|}{ Other plan characteristics (\%) } \\
\hline $\mathrm{N}$ funds offered (mean) & 65.8 & 45.5 & 30.3 & 27.7 & 28.2 & 28.3 & 28.6 & 29.3 & 28.7 \\
\hline Employer stock offered & 0.0 & 15.5 & 38.5 & 45.0 & 46.9 & 46.8 & 46.7 & 44.5 & 45.0 \\
\hline Loan offered & 3.5 & 44.2 & 70.5 & 79.9 & 84.6 & 85.2 & 85.8 & 85.5 & 85.5 \\
\hline SA_before & 100.0 & 70.8 & 43.8 & 37.0 & 44.3 & 50.4 & 54.2 & 55.0 & 52.0 \\
\hline \multicolumn{10}{|l|}{ Participant characteristics } \\
\hline Log balance (mean 2010\$) & 9.9 & 9.9 & 10.1 & 10.0 & 10.0 & 9.6 & 9.9 & 10.1 & 9.7 \\
\hline New entrant (\%) & 1.6 & 8.9 & 13.5 & 22.8 & 28.3 & 35.9 & 40.5 & 43.6 & 42.6 \\
\hline Job tenure (years) & 4.7 & 7.6 & 9.8 & 9.3 & 9.3 & 9.4 & 9.8 & 10.2 & 9.4 \\
\hline Young (<35, \%) & 23.6 & 24.8 & 24.2 & 24.8 & 24.4 & 24.4 & 23.0 & 22.4 & 25.3 \\
\hline Middle (35-55, \%) & 63.7 & 61.5 & 60.9 & 59.7 & 59.9 & 58.4 & 58.3 & 57.8 & 55.4 \\
\hline Old $(>55, \%)$ & 12.7 & 13.7 & 14.9 & 15.5 & 15.7 & 17.2 & 18.7 & 19.7 & 19.2 \\
\hline Male (\%) & 34.7 & 39.7 & 43.0 & 53.9 & 57.9 & 56.7 & 57.1 & 57.6 & 56.2 \\
\hline HH income low $(<\$ 62.5 \mathrm{~K}, \%)$ & 18.5 & 20.4 & 19.4 & 23.3 & 23.4 & 23.3 & 22.0 & 21.0 & 21.7 \\
\hline HH income medium (\$62.5-\$87.5K, \%) & 35.5 & 43.9 & 41.3 & 36.8 & 37.4 & 37.1 & 37.6 & 38.0 & 39.9 \\
\hline HH income high $(>\$ 87.5 \mathrm{~K})$ & 46.1 & 35.7 & 39.3 & 39.9 & 39.2 & 39.6 & 40.4 & 41.0 & 38.4 \\
\hline \multicolumn{10}{|l|}{ Non-ret. Financial Wealth } \\
\hline Low $(<\$ 7.3 \mathrm{~K}, \%)$ & 9.5 & 38.1 & 43.6 & 43.7 & 42.3 & 42.5 & 44.6 & 42.1 & 43.5 \\
\hline Average (\$7.3K-\$61.2K, \%) & 43.6 & 35.1 & 34.7 & 34.9 & 34.2 & 34.2 & 35.4 & 36.4 & 35.5 \\
\hline High $(>\$ 61.2 \mathrm{~K}, \%)$ & 46.9 & 26.8 & 21.8 & 21.4 & 23.5 & 23.2 & 19.9 & 21.6 & 21.0 \\
\hline \multicolumn{10}{|l|}{ Financial Crisis } \\
\hline Financial crisis (\% of year) & 0 & 0 & 0 & 0 & 0 & $1 / 3$ & $1 / 3$ & 0 & 5.7 \\
\hline \multicolumn{10}{|l|}{ TDF adoption (\% of accounts) } \\
\hline TDF investor & 0.2 & 4.8 & 14.9 & 19.5 & 25.9 & 35.2 & 39.4 & 44.0 & 41.4 \\
\hline Pure TDF investor & 0.1 & 2.8 & 7.2 & 10.8 & 15.5 & 23.7 & 27.4 & 31.5 & 29.6 \\
\hline Mixed TDF investor & 0.0 & 2.0 & 7.7 & 8.7 & 10.4 & 11.5 & 12.0 & 12.5 & 11.8 \\
\hline \multicolumn{10}{|l|}{ Observations } \\
\hline $\mathrm{N}$ plans & 7 & 136 & 287 & 485 & 716 & 879 & 966 & 1,008 & 1,008 \\
\hline $\mathrm{N}$ accounts & 10,150 & 142,130 & 380,325 & 679,188 & $1,137,428$ & $1,487,507$ & $1,556,295$ & $1,543,320$ & $2,202,411$ \\
\hline
\end{tabular}

Note: In individual years 2003 through 2010, characteristics are measured as of final contribution date in each calendar year for full sample including new entrants; each observation represents one account. In 2003-2010 summary, characteristics are measured as of the contribution date for the full sample including new entrants; each observation represents one account.

Source: Authors' computations. 